Hispania Sacra, LX

122, julio-diciembre 2008, 735-766, ISSN: 0018-215-X

\title{
OTRO PROYECTO DE PRESENCIA DE LOS CATÓLICOS EN LA POLÍTICA (1930-1936)*
}

\author{
POR \\ CRistóbal Robles MuÑoz \\ Instituto de Historia, CSIC
}

\begin{abstract}
RESUMEN
Libre de la presión del legitimismo, primero confesional y luego laico según el modelo de la Action Française, los católicos inauguran en el rl primer tercio del siglo XX una forma de presencia nueva. Eso exigía una organización nueva: un partido que creara electores, no oficinas electorales. El elector debe llegar a ser un ciudadano capaz de entender las situaciones sociales, económicas y políticas y pronunciarse ante ellas. Esa tarea era una parte de la educación moral en una sociedad democrática. Era, al mismo tiempo, una opción para que la Iglesia jamás abandonara la libertad alcanzada al independizarse del poder y al reconocer la libertad política de los católicos.
\end{abstract}

Palabras ClaVe: Legitimismo Ralliement, León XIII, Pío XI, Action Française, República, Francia, Portugal, España.

\section{ANOTHER PROJECT OF PRESENCE OF CATHOLICS IN THE POLITICS (1930-1936)}

\begin{abstract}
Free of the pressure of legitimist positions, first confessional and then lay according to the model of Action Française, the Catholics inaugurate in the first
\end{abstract}

* AHN/GC: Archivo Histórico Nacional Guerra Civil, Salamanca.

SV AES: Archivio Segreto Vaticano, Affari Ecclesiastici Straordinari, IV periodo, posizione, fasscicolo pagina.

AES SS: Archivio Segreto Vaticano, Segreteria di Stato, rubricva, anno, fascicolo, pagina.

DS/C: Diario de las Sesiones de las Cortes. Congreso de los Diputados. 
third of the XXth century a form of new presence. That was demanding a new organization: a party that was creating electorate, not electoral offices. The elector had to become a citizen able of understanding the social, economic and political situations, to declare itself on them. This task was a part of the moral education in a democratic society. It was, at the same time, an option so that the Church was never leaving the freedom reached on having become independent of the power and on having recognized the political freedom of the Catholics.

KEY WORDS: Legitimist positions, Ralliement, León XIII, Pío XI, Action Française, Republic, France, Portugal, Spain.

Recibido/Received 20-01-2007

Aceptado/ Accepted 18-04-2008

¿Qué deseaba León XIII para los católicos en países como Francia, España y Portugal? Les puso como horizonte «desistir de los procedimientos de rebelión, de la apelación a la violencia, de aquello que está en contra del espíritu cristiano y de los más sagrados intereses de la Patria» ${ }^{1}$. La justicia y el bien común bastan para legitimar las instituciones políticas que cada pueblo se $\mathrm{da}^{2}$. Ralliement significa aceptar los poderes constituidos y actuar dentro de ellos. Era optar por la legalidad frente a la insurrección ${ }^{3}$.

\section{ANTECEDENTES LEGITIMISTAS}

Un parte importante del catolicismo hasta 1887 no fue constitucional por motivos dinásticos. Fue legitimista, es decir, carlista. Creían que la legitimidad se quebró en septiembre de 1833, a la muerte de Fernando VII.

En 1887 ese bloque se rompe en dos facciones: los leales y los integristas. Hay un antecedente unos años antes. Ese sector católico-carlista, comenzó a situar la legitimidad no en la sucesión, sino en los principios religiosos. Don Carlos era su Rey porque personificaba la monarquía católica. Por eso quiso llamarse «comunión católico-monárquica» ${ }^{4}$. Se creaba así una solidaridad

\footnotetext{
1 «Católicos sí; facciosos, no», El Imparcial, 1 de septiembre de 1899, 1.

2 «No hay razón para que la Iglesia desapruebe el Gobierno de un solo hombre o de muchos, con tal de que ese Gobierno sea justo y atienda al bien común. Por lo cual, salvada la justicia, no está prohibido a los pueblos la adopción de aquel sistema de Gobierno que sea más apto o conveniente a su manera de ser, o a las instituciones o costumbres de sus mayores». León XIII, «iuturnum illud bellum» n. 4, 29 junio 1881, Doctrina Pontificia II: Documentos Políticos, Madrid, Editorial Católica 1958, 111-112.

${ }^{3}$ Sobre este proceso en su recorrido desde 1875 hasta 1914, Insurrección o legalidad, Madrid, Publicaciones del CSIC 1988 y Andrés MARTínez EsteBAn, Aceptar el poder constituido. Los católicos españoles y la Santa Sede en la Restauración (1890-1914), Madrid, Publicaciones de la Facultad de Teología «San Dámaso», Studia Theologica Matritensia 9, 2006.

${ }^{4}$ Informes de Cándido Nocedal y de Ramón Nocedal al cardenal Jacobini, 9 de febrero de 1882, ASV SS 249 (1882) II 156-157 y Cándido Nocedal-Jacobini, 21 y 26 de marzo de 1882, ibidem 183185 y $199-202$.
}

Hispania Sacra, LX

122, julio-diciembre 2008, 735-766, ISSN: 0018-215-X 
excesiva entre forma de Estado y catolicismo. No bastaba llamar a la unidad, porque esta nunca es una fusión de cosas diversas.

\section{a. El caso francés}

Para resolver las contradicciones que provocaba esa actitud, tuvo León XIII que manifestar abiertamente su pensamiento. No bastaban los encargos ${ }^{5}$. Era preciso que él mismo declarara que la Iglesia no tenía alianzas políticas. No hipotecaba su porvenir a una forma de gobierno ni a la restauración de una legitimidad vencida

No impondría a sus fieles otra adhesión que la de la fe en Dios, la aceptación de los principios católicos y la obediencia a la autoridad eclesiástica. Ese acto fue la $\underline{A u \text { Milieu }^{6}}$. Estos eran sus puntos principales:

1. León XIII denunciaba la persecución contra el catolicismo. Convocaba a todas las personas honestas y sensatas, porque había que suprimir todo germen de división entre ciudadanos y consolidar la paz interna.

2. Sobre la organización de los católicos, la postura del Papa era cautelosa y poco precisa. No se despejaba si se trataba de un partido político, confesional o de crear una estructura religiosa que, actuara, más allá de las justas opciones de cada uno, como un grupo de presión, unido y fuerte, para garantizar la libertad y los derechos de la Iglesia ${ }^{7}$. Posiblemente eso hubiera quedado más claro si se hubiera conocido entonces la oposición de León XIII a llamar «Unión Católi$c a »$ a la presencia pública, política y social, de los católicos, primero en España y luego en Francia.

3. La Iglesia no buscaba la dominación política, tal como denunciaban los anticlericales. Los cambios políticos eran resultado de la evolución social. Una vez constituidos los nuevos poderes, aceptarlos era lícito y hasta obligatorio ${ }^{8}$.

\footnotetext{
${ }^{5}$ Lamentando el escaso eco que había tenido su decisión de pedir una adhesión a la República, el cardenal Lavigerie juzgaba imprescindible una intervención directa y clara de León XIII. 22 de abril de 1891, Lavigerie-Domenico Ferrata, secretario de la Congregación de Asuntos Eclesiásticos Extraordinarios y antiguo secretario de la nunciatura de París. Texto publicado en X. de MontClos, Le toast d'Alger. Documents, Paris 1966, 391-392. Sobre estas gestiones hasta su nombramiento como nuncio en París, en julio de 1891, D. FerRata, Mémoires II, Roma 1920, 8-55.

6 «Encíclica de Su Santidad el Papa León XIII a los arzobispos, obispos, al clero y a todos los católicos de Francia», 16 de febrero de 1892, La Cruz 1 (1892) 241-255. Hay una traducción latina, que no se publicó jamás. ASV SS 248 (1900) II 21-242. Hubo interés en quitar el menor pretexto a las interpretaciones polémicas.

${ }^{7}$ Doctrina Pontificia II. Documentos políticos, Madrid 1958, nn. 8 y 31, 300-302 y 308.

${ }^{8}$ Es el aspecto más nuevo de la encíclica, nn. 18-24, ib. 305-306. Se advirtió entonces que esta decisión de León XIII parecía establecer una excepción con el Reino de Italia, única entidad revoluciona-
} 
En todo régimen constitucional debería distinguirse entre los titulares de la autoridad y la legislación. Esta respondía a programas y dependía de la composición de los parlamentos, elegidos periódicamente. Podía aspirarse a modificar las leyes, sin poner en tela de juicio las instituciones constitucionales y los procedimientos reformadores sancionados en ellas 9 .

4. Había que aceptar, «sin reservas y con la lealtad perfecta que conviene al cristiano, el poder civil en la forma en que de hecho existe» por razones de bien común ${ }^{10}$.

El documento pontificio es posterior a una declaración del gobierno presidido por Loubet hecha el 3 de marzo ante la Asamblea Nacional: la República «n'est pas seulement une forme de gouvernement; elle répresente l'ensemble des institutions nées de la Révolution Française».

León XIII había hecho una opción de futuro. Su perspectiva no era inmediata. Sabría esperar ${ }^{11}$. Seguiría el rumbo de una Iglesia que eligió acercarse al pueblo ${ }^{12}$ y moralizar la vida pública. El Papa había dirigido «muchas veces la palabra a la nación francesa para manifestar a todos los hombres (sensatos) y de buena voluntad la necesidad de aceptar, de común acuerdo, la forma de gobierno constituida; aceptación que es el único medio de llegar, por la práctica común de todas las energías, a restablecer la paz religiosa y, con ella, la concordia entre los ciudadanos, el respeto a la autoridad, la justicia y la honradez en la vida pública» ${ }^{13}$.

ria que el Papa prohibía a los católicos reconocer. Sobre el fracaso de las gestiones de Fazzari y Tosti entre 1885 y 1887, G. Spadolini, L'opposizione cattolica da Porta Pia al '98, Firenze 1954, 220 y ss.

${ }^{9}$ Ib. nn. 26-27 y 32, 307-308.

${ }^{10}$ Resumen de su documento dado por el Papa en la carta a los cardenales franceses el 3 de mayo de 1892, «Notre consolation», 10-11, ib. 315. Insistió en este planteamiento en la «Praeclara gratulationis», 20 de junio de 1894, n. 15, ib. 338.

${ }^{11}$ Confidenziale. Rampolla-Ferrata, 16 de febrero de 1892. No se encuentra este documento, pero lo cita en nuncio. Confidenziale. Ferrata-Rampolla, 8 de marzo de 1892, AES Francia 449/857, 65-67. El Papa había adoptado esta posición desde el comienzo de su pontificado. «Carta al Cardenal Arzobispo de Malinas y a los obispos de Bélgica», 3 de agosto de 1881, La Cruz 2 (1881) 360. Habían ganado las elecciones los liberales y se había despedido al nuncio en Bruselas. Ferrata, una persona clave en esta estrategia de la Iglesia, fue nuncio en Bruselas en los años inmediatos a su nombramiento de secretario de la Congregación vaticana que trataba de las relaciones con los Estados. Sobre esta gestión, D. Ferrata, o.c. v. I.

${ }^{12}$ En esa paciente espera y en la certeza de que así se llegaba hasta el pueblo, cifraba John Ireland, arzobispo de St. Paul (Minnesota), el porvenir y el éxito de la decisión tomada por León XIII. IrelandRampolla, 27 de junio de 1892, ASV SS 248 (1900) VI 54-57. Ireland se había entrevistado con el presidente Sidi Carnot, con Ribot, con Jules Ferry y con algunos diputados de izquierdas, durante una estancia en París y Lyon.

${ }^{13}$ En la política debían prevalecer «la libertad, la justicia, la honradez y el respeto debido a las creencias de la gran mayoría de los franceses». «Carta de Su Santidad León XIII al conde Alberto de Mun», 7 de enero de 1893, La Cruz 1 (1893) 143-145.

Hispania Sacra, LX

122, julio-diciembre 2008, 735-766, ISSN: 0018-215-X 


\section{b. La sorpresa en España}

El gesto hacia la República Francesa fue percibido en España. Pi y Margall afirmó que León XIII era uno de los «diplomáticos más hábiles que hay hoy en Europa» ${ }^{14}$. Entre los católicos causó «un movimiento de sorpresa»15. El documento fue calificado «del mayor interés». Ciriaco María Sancha, entonces obispo de Madrid-Alcalá, buen conocedor de la situación de la Iglesia en Europa y abierto a las nuevas ideas, vio en la encíclica la respuesta a la exposición de los cinco cardenales franceses, denunciando la persecución que sufría el catolicismo en su país ${ }^{16}$. Se quedó en el primer punto del proyecto de ralliement.

\section{COLABORACIÓN CON LAS PERSONAS HONESTAS VERSUS CONFESIONALISMO}

León XIII denunció la desobediencia de quienes alardeaban de católicos y se mostraban «refractarios a la dirección impuesta por el Jefe de la Iglesia, bajo el pretexto de que se trata de una cuestión política». Era una aviso, para asentar el principio de que el catolicismo sabría conciliarse con las personas honestas y ganar su cooperación, pues, «al mantenerse firme en la proclamación de los dogmas y limpia de todo compromiso con el error, la prudencia cristiana no rechaza, mejor dicho, sabe conciliarse, al buscar el bien, sea individual, sea sobre todo social, el concurso de todos los hombres honrados» ${ }^{17}$.

En Francia, la III República se había consolidado. En España, la Restauración no se orientaba según las aspiraciones del clero y de los católicos tradicionalistas. Para desbloquear la situación se realizaron en ambos países varios ensayos. Todos ellos buscaban articular una organización conservadora más

14 «... el poder que tiene la Iglesia es el poder que cada pueblo le concede». Su discurso fue un buen resumen del pensamiento del Papa. Sus alusiones a la cuestión romana fueron juzgadas por Cánovas una descortesía que rompía una de las convenciones existentes entre todos los partidos de las Cortes españolas. La intervención de Pi y Margall, DS/C 195 (10 de mayo de 1892) 5656. La réplica de Cánovas, ib, 5657.

15 «... la última encíclica de Su Santidad... ha producido en ciertos elementos católico-políticos de España un movimiento de sorpresa, suscitándose algunas dudas sobre la verdadera inteligencia de la misma». Salvador Casañas-Rampolla, 2 de junio de 1892, ASV SS 248 (1900) IV 23.

16 «El Romano Pontífice y la Francia», Boletín Eclesiástico de Madrid-Alcalá 237 (18 de marzo de 1892) 133-134.

17 «... si es cierto que el progreso de la vida religiosa de los pueblos es una obra eminentemente social, dada la estrecha relación que existe entre las verdades que son alma de la vida religiosa y aquellas que sigue la vida civil, resulta aquí una regla práctica... que da a los católicos una característica amplitud de espíritu». «Carta de Su Santidad el Papa León XIII al Iltmo Sr. Obispo de Grenoble», 22 de junio de 1892, Boletín Eclesiástico de Cartagena y Murcia 22 (1 de agosto de 1892) 173-176. 
extensa que el legitimismo y que el carlismo ${ }^{18}$. En cualquier caso, la acción política era imprescindible. Los legitimistas creían que, siendo inseparables religión y política, ésta debía ser monárquica en Francia y carlista en España.

La indiferencia y el retraimiento político conducían a la dictadura, como único remedio a los excesos revolucionarios. La defensa del orden material llevaba directamente al despotismo. «La défense religieuse n'était pas séparable de la lutte politique que devait susciter la dictature générale de la République sur la France»19.

El disentimiento constitucional de los católicos en España y Francia los condujo a patrocinar la estrategia del mal mayor: era necesario provocar a los poderes constituidos, porque, de ese modo, se desvelaba que eran enemigos del catolicismo. Había que destruir las instituciones existentes para poder alcanzar «el bien supremo» 20 .

Desde ese horizonte, parecía lícito utilizar la religión para fines políticos ${ }^{21}$. La monopolizaron los legitimistas el catolicismo y le dieron un color sectario.

En España, la fracción del carlismo capitaneada por Cándido Nocedal se propuso «hacer un verdadero monopolio de la religión, valiéndose de ella para que prevalezca su bandera siendo su temerario empeño sostener que no hay más católicos que los afiliados a su bando y que ellos son los únicos que sostienen el movimiento religioso en España». Todos, también los obispos, tenían que someterse al jefe del partido carlista22. En todas las palabras del Papa vieron la aprobación de su comportamiento y un elogio de sus obras en favor del catolicismo ${ }^{23}$.

18 Eso pretendió ser en España la Unión Católica. J. M. MAGAz, La Unión Católica (1881-1884) Roma 1989. C. RoBles, «La Unión Católica, su significación y su fracaso», Burgense 28/1 1987) 109168. La Unión Católica tuvo a su favor al principio la división dentro del campo carlista. Recibió la adhesión de los que se oponían a la dirección de Nocedal.

${ }^{19}$ Dicurso de A. de Mun en el castillo de Limoges, 8 de marzo de 1881. La monarquía era la «contre-révolution chrétienne». Ph. LEVILLAIN, Albert de Mun, catholicisme frannçais et catholicisme romain, du Syllabus au Ralliement, Paris-Rome 1983, 690-695 y 757-759.

${ }^{20}$ En marzo de 1881, la derecha planteó una interpelación en el Senado francés sobre los institutos regidos por los jesuitas. El Senado había votado contra el artículo VII de la ley que excluía de la enseñanza a los religiosos pertenecientes a congregaciones no autorizadas. Con esa iniciativa parlamentaria provocaban al bloque republicano para que llevara hasta el final su política y expulsara a los jesuitas. 265 Czacki-Jacobini, 17 de marzo de 1881, ASV SS 248 (1881) II 70-71.

${ }^{21}$ En esos días de marzo de 1881, el arzobispo de Sens denunció a los católicos que, siendo «avant tout hommes de parti», agravaban las tensiones sin pararse siquiera ante la separación Iglesia-Estado, una de las proposiciones que había condenado el Syllabus. V. F. Bernardin-Léon XIII, 24 de marzo, AES Francia 373/725, 2-3.

22 Urquinaona-Jacobini, 17 de octubre de 1882, ASV AES 216/695, 2-3. Sobre los conflictos del obispo de Barcelona con los carlistas, con su diario, El Correo Catalán y con la Juventud Católica, controlada por ellos, ib. 4-10.

${ }^{23}$ «Los verdaderos tradicionalistas», El Correo Catalán, 18 de octubre de 1882.

Hispania Sacra, LX

122, julio-diciembre 2008, 735-766, ISSN: 0018-215-X 
León XIII proponía un proyecto nuevo: presencia de la Iglesia en la escuela, acción social, predicación y catequesis. La defensa de los derechos del catolicismo debía plantearse por medios legales ${ }^{24}$. Los católicos tenían que observar los preceptos de la Iglesia y respetar la autoridad. Obligación de los obispos era amonestar a los pueblos para que no se afiliaran a «las sectas prohibidas», abandonaran las conjuras y nada intentaran «por medio de la revolución» ${ }^{25}$.

Se buscaba una plausibilidad social. Porque la tesis católica, tal como estaba presentándose, aparecía plagada de prejuicios y malentendidos, levantando «comme une muraille entre une societé qui périt et l'Église qui garde seule les moyens de la sauver» ${ }^{26}$. Desde esa perspectiva, la neutralidad de la Iglesia no contemplaba como único fin vencer el recelo de los políticos liberales. Era también una condición para restablecer sus lazos con el pueblo y con todos los que sufren ${ }^{27}$.

\section{UNA PROPUSTA DE RALLIEMENT PARA PORTUGAL}

Un católico portugués preguntaba en 1933 si los católicos sabían en qué mundo vivían: las monarquías iban a desaparecer de Europa. No cabían en ese mundo las pretensiones de Action Française ni el restablecimiento de la situación anterior a la separación Iglesia-Estado.

\section{a. Los católicos portugueses, los obispos y la Action Française}

El 26 de enero de 1927, el secretario del arzobispo de Evora planteaba la necesidad de que la Santa Sede dejara clara su condena de la Action Française. No debían permitirse interpretaciones que la anulaban basándose en lo que se llamaba «sobre-entendidos» en los documentos sobre ella ${ }^{28}$.

24 «Discurso de Su Santidad a los peregrinos franceses», mayo de 1881, La Cruz 1 (1881) 780.

25 León XIII, Diuturnum Illud, 29 de junio de 1881, Doctrina Pontificia. II. Documentos políticos, Madrid 1958, n. 20, 126.

${ }^{26}$ Declaraciones de Mgr. d'Hulst, vicario de París y rector del Instituto Católico de aquella ciudad, publicadas en L'Univers, 2 septembre 1881. Texto reproducido en A. LECANUET, L'Église de France sous la Troisième République, II. Pontificat de León XIII, 1878-1894, Paris 1910, 187-188.

27 «...quando sono qui giunto (ottobre 1878), gridavano ai quatro venti della terra: che ogni governo moderno, essendo un cancro sociale, nessuno, compresavi la Chiesa, poteva avvicinarsene. Ma con simile teoria avrebbero potuto egualmente esigere dalle suore della Carità di non aviccinarsi agli ulceri fisici dell'umanità sofferente». 382 Czacki-Jacobini, 28 de febrero de 1882, ASV SS 248 (1882) I 116-120.

${ }^{28}$ La carta sin otro destinatario que «Mon très cher Monseigneur», 26 enero 1927, en ASV AES Portogallo 35073 8-9. Unos días antes el arzobispo de Braga, Manuel Vieira de Mattos, pidió a la Santa Sede palabras de ánimo para Novidades el diario católico editado en Lisboa. 
Unos días antes el arzobispo de Braga, Manuel Vieira de Mattos, pidió a la Santa Sede palabras de ánimo para Novidades el diario católico editado en Lisboa. La demanda suponía una censura a su rival Epoca, también un diario católico. El arzobispo calificaba «opera di tradimento» su indisciplina y desobediencia a la Santa Sede y a los obispos. Estaba dividiendo a las fuerzas católicas.

Pese a la censura de los obispos, durante dos años el diario respondió que seguiría consecuente con sus principios y siempre obediente a la Iglesia. «E la doppia faccia tanto cara ai modernisti». Para Epoca la condena de la Action Française era una simple polémica entre el diario con este mismo nombre y el oficioso de la Santa Sede, L'Osservatore Romano. Nada les hacía rectificar, ni siquiera la serie pubicada por Novidades. Sus redactores, denunciando la posición de Epoca, habían manifestado su fidelidad a la Iglesia y a la Santa Sede. Lo hacían hasta con heroísmo, dada la tensión existente entre los católicos conservadores. Un gesto de la Santa Sede acabaría con la ambigüedad y facilitaría la recuperación de la unidad ${ }^{29}$.

Sebastiano Nicotra, nuncio en Lisboa, envió un dossier completo al cardenal Pietro Gasparri. Muchos de los miembros de Action Française eran monárquicos. El nuncio pensaba pedir instrucciones para que la Santa Sede ordenara a los obispos portugueses que dijeran a sus fieles que no podían leer Action Française, porque estaba condenado por el Papa. Epoca sostenía que Pío XI dejaba total libertad a los católico. Reiteró su obediencia a la Iglesia y su condición de independiente respecto a los partidos. Era un diario nacional independiente. No se confesaba como diario católico, pero colocaba en primer plano la religión y la Iglesia ${ }^{30}$.

Tras la censura del Patriarca, cerró Epoca y apareció $A V \mathrm{Vz}^{31}$. Era en realidad el mismo periódico suspendido. Seguía la misma orientación ${ }^{32}$.

El 6 de abril de 1927 los obispos portugueses del continente publicaban una pastoral a sus fieles comunicando que el Papa había condenado a Action

\footnotetext{
${ }^{29} \mathrm{El}$ arzobispo era el presidente de la Comisión Episcopal interdiocesana de prensa. Manuel Vieira de Mattos-Pietro Gasparri, 22 enero 1927, ibidem 12-14.

${ }^{30}$ Había una coincidencia entre los jesuitas el grupo del que era portavoz Epoca. Vid, 3197 Efrem Forni, encargado de negocios, Pietro Gasparri, 8 octubre 1927, ibidem 42 verso-45. Los informes sobre este asunto enviados por los obispos de Braganza, 18 agosto, los apuntes del vicario general de Lisboa, y el obispo de Portalegre, Coimbra, Beja, Guarda y el canónigo Fernando Paes de Figuereido, copias sin fecha, ibidem 46-63.

${ }^{31} 1907$ Nicotra-Pietro Gasparri, 3 febrero 1927, ibidem 18-19.- Anexos con la traducción italiana de dos cartas del vicario general de Lisboa 19 y 20 de enero, ibidem 20-22. Las dos fueron publicadas como «A ultima prova», Novedades 22 enero. Hay un sobre con los recortes de prensa enviados por el nuncio a petición del cardenal Gasparri.

${ }^{32}$ Manuel Vieira de Mattos-Pietro Gasparri, 15 febrero, ib ibidem 39. Le enviaba un ejemplar de A Voz.
}

Hispania Sacra, LX

122, julio-diciembre 2008, 735-766, ISSN: 0018-215-X 
Française $^{33}$.La situación del nuncio se deterioró ${ }^{34}$. El Papa respondió el 17 mayo al episcopado con una carta al patriarca António Mendes Bello ${ }^{35}$. El nuncio quedó desautorizado ${ }^{36}$. A mitad de julio la correspondencia se dirige a Efrem Forni, encargado de negocios.

Restablecidas las relaciones diplomáticas, interesaba a Portugal recuperar su secular posición ante la Santa Sede. Eso significaba, como sucedió en Francia, «un nuevo espíritu». ¿Podía la Iglesia pedir justicia para sus reivindicaciones sin percibir que las presentaba ante una instancia diferente a la que le había dado algunos de sus derechos y respetado muchos de sus intereses lesionados?

En el segundo Gobierno de Oliveira Salazar entró como ministro de Exteriores Henrique Trindade de Coelho. En declaraciones a la prensa, afirmó que la Iglesia, por patriotismo, debería renunciar a una satisfacción inmediata de sus justas reclamaciones, que era obligado atender más adelante. Se conformaba con el mínimo. La dictadura, representante del bien de la nación, no comprometería su labor reconociendo unas aspiraciones justas, pero prematuras. El contemporizar, por regla general, es una norma buena para alcanzar la armonía y la paz. Había que ir a un nuevo concordato. En el Vaticano, Pío XI, el cardenal Pietro Gasparri y Mgr Pizzardo amaban a Portugal. Estas declaraciones eran un gesto atrevido y poco oportuno. Provocó alarmas y movilizaría a quienes se oponían a ese giro. Faltó discreción ${ }^{37}$.

332018 Nicotra-Pietro Gasparri, 19 abril, con anexo, ibidem 52-54. El nuncio la tradujo al italiano. L'Ossevatore Romano la publicó el sábado 30 de abril. Hay una copia en portugués, ibidem $3517414-$ 20. Una copia de la carta de los obispos al Papa, enviando su pastoral colectiva, abril 1927, ibidem 3132. Un apunte sobre Nicotra durante su etapa en su etapa de Auditor en la nunciatura de Viena, Giovanni Semeria, Anni Terribili. Memorie inedite di un «modernista» ortodoxo (1903-1913), Cinisello Balsamo (Milano) Edizioni San Paolo m2008, 235-243.

34 Esta conclusión la redactó Pietro Gasparri después de una audiencia con el Papa, 1519/27, 7 mayo 1927, AES Portogallo 35174 8. Era la respuesta a 2044, 28 abril 1927, ibidem 74 3-6. Un dossier sobre Fernando de Sousa (Nemo), su director, ibidem posizione 35073 43-46. El nuncio en Lisboa Giovanni Beda Cardinale desaconsejó que el papa recibiera en audiencia pública a Mendes Sousa en enero de 1933. Recordaba los ataques de este al Centro Catolico, Se reiteró esa comunicación en mayo de 1935. ibidem 67-78.

35 Vid las dos minutas del documento, 1613/27, ibidem posizione 351 fascicolo 74 10-12. La respuesta del patriarca, 8 junio, ibidem 30 y la del Papa, 25 junio, ibidem 34.

36 Vid. Su extensa carta particular y autógrafa, 30 mayo, ibidem 22-27.

37511 Beda-Gasparri, 26 julio 1929, ASV AES Portogallo, posizione 360 fasc 95 28-29. Vid. «Novo Ministro dos Negocios Estrangeiros», Diario de Noticias 26 julho 1929, 1. El ministro dimitió porque un grupo de masones organizó un homenaje ante la tumba del padre de Trindade de Coelho, que había sido masón y escritor anticlerical y que se suicidó. Coelho era una convertido. Tenía a su lado un grupo de jóvenes oficiales. Pidió ser embajador ante la Santa Sede. Esta situación provocó una novedad: el Gobierno pidió la aceptación de la Santa Sede. El embajador anterior fue trasladado a Berlín. 604 Beda-Pietro Gasparri, 27 agosto 1020, ibidem 34. Su sucesor fue Jaime da Fonseca Monteiro, oficial de la Marina. Procedía de la izquierda. Era un gesto para satisfacer a quienes tachaban al Gobierno de ser excesivamente conservador, 642 Beda-Pietro Gasparri, 6 octubre, ibidem 38. 


\section{b. El ralliement de Oliveira Salazar}

En la noche del 23 de noviembre de 1932 Oliveira Salazar, rodeado de las autoridades del País, se dirigió por radio a la nación. Se mostró seguro en el tono y claro en el contenido de sus palabras ${ }^{38}$. Examinó lo sucedido entre 1930 y 1932 y puso la unidad nacional como base del Estado nuevo. Portugal tiene que elegir la vía de la seguridad y del bienestar. Anunció una reforma política, económica y social hecha sin ofender a nadie.

La monarquía había muerto con Manuel II, a quien elogió. La idea republicana se había impuesto a la monárquica en toda Europa. Respetaba las convicciones sinceras, pero pedía a los monárquicos que pensaran si eran realizables las suyas. Importan las formas menos que los principios en los que se organizan el poder y las instituciones. Eran tiempos de incertidumbre. Europa estaba en una encrucijada.

¿Qué habían hecho los católicos desde 1922? Aquel año Salazar intervino en el Congreso de Centro Católico. Por su propia experiencia, estaba a favor de que los católicos, mancomunados en el Centro Católico, se dedicaran exclusivamente a la acción social.

La alianza religión y política en Portugal perjudicaba a la Iglesia. Estaba seguro que las cuestiones entre la Iglesia y la República perderían virulencia si se dejara a un lado la cuestión del régimen. Eso significaba alejarse de los monárquicos militantes. En la Acción Católica, en el Centro Católico, deberían alojarse los que prescindían de las formas de gobierno sin reservas mentales. Por este camino se obtendrían mayores ventajas.

La buena fe de muchos fue atropellada por la incultura y la intolerancia de los jacobinos, que estaban en los partidos avanzados. Se forjó así la mentira de que la República portuguesa era enemiga de los católicos. Este sectarismo abrió llagas profundas en la nación.

La dictadura haria innecesario el Centro Católico ${ }^{39}$. El Gobierno protegería a la Iglesia si aceptaba esta invitación de Salazar a dedicarse a la acción social. La confusión entre política y religión iba contra los intereses de los pueblos, perjudicaba el desarrollo de la vida religiosa. En un país con tradiciones católicas antiguas, pero con una cultura escasa, la intervención de la Iglesia en política le causaba siempre serios problemas: hace que contra ella se dirijan quejas y sospechas graves que perjudican su misión espiritual.

\footnotetext{
${ }^{38}$ El secretario de la nunciatura, Adolfo Todini, envió un resumen en italiano anotado Copia manuscrita, ASV AES Portogallo, posizione 384 fasc 146 35-54. La carta de Tonini a Pizzardo, 24 noviembre, ibidem 55-56.

${ }^{39}$ Adolfo Todini anota: ¿Se alude a la firma de un concordato?

Hispania Sacra, LX

122, julio-diciembre 2008, 735-766, ISSN: 0018-215-X
} 
Los católicos siguieron el camino de la acción política cuando los Estado les negaban la libertad y abogaban por una irreligiosidad positiva, oculta en una «neutralidad oficial». Esa reacción fue entonces legítima.

Oliveira Salazar se fijaba en estos dos puntos: separación $\mathrm{n}^{40}$, y relaciones diplomáticas. Estas se regularían con un Concordato, pero dejando a salvo el «Padroado» en Oriente. Había más: las circunstancias impedían al gobierno portugués reparar las injusticias y atender las reivindicaciones de la Iglesia ante los abusos cometidos contra ella por la República. Este esquema de relaciones con la Iglesia dejaba sin misión al Centro Católico

\section{EL RALLIEMENT: SUS ESCENARIOS EN ESPAÑA}

Hasta la II República y a diferencia de otros países, no existió en España una política sectaria que empujara a los católicos a aliarse con todos los que defendían las libertades. Al contrario, la libertad actuaba contra la pretensión de los católicos de monopolizar el derecho a la existencia legal dentro de la nación. Las cosas variaron en el cambio de siglo. En abril de 1931, los católicos españoles llevaban varios años creyéndose perseguidos, juzgando la política anticlerical de los gobiernos liberales hostil a los derechos e intereses de la Iglesia.

Algunos creyeron que el vuelco político culminaría ese proceso de hostigamiento. El 15 de diciembre de 1931 aparecía Acción Española. La República no era un cambio en la encarnación de la suprema magistratura de la nación. Por eso fue ilusoria la hipótesis de una República respetuosa con las bases del orden social cristiano o aun del orden natural. Esperar eso era una utopía irrealizable. Ese fue un error de León XIII: creía que la República postulaba la separación Iglesia-Estado y perseguía a la Iglesia porque los católicos no habían aceptado la III República Francesa.

En Acción Española ${ }^{41}$, publicó Eugenio Vegas Latapié una serie de artículos, recogidos luego en su «Catolicismo y República». Era su aportación a la campaña crítica que los sectores monárquicos iniciaron inmediatamente. Se prolongaría hasta la obra de Pedro M. Vélez, un historiador agustino, La revolución y la contrarrevolución mundial en España. El fracaso de una táctica y el camino de la Restauración. En este libro, editado en 1936 y destruido, un «li-

\footnotetext{
${ }^{40}$ Cuando Sidonio Pais restableció las relaciones diplomáticas, parecía que la Santa Sede aceptaba la separación que se le impuso en 1911.

${ }^{41}$ Los números editados por esta revista pueden verse en http://www.filosofia.org/hem/193/acc/index.htm, una página creada por el portal «Proyecto de Filosofía en español». Siendo una antología, no se encuentran los de Vegas Latapié.
} 
bro mártir», lo llama Vegas Latapié, autor del prólogo, se atacaba duramente a Ángel Herrera, por haber aceptado la «teoría del mal menor» ${ }^{42}$. Vegas exculpaba a Ángel Herrera y a El Debate: su buena fe y su amor a la religión y a la patria no les libraron del traspié. Se equivocaron ${ }^{43}$. Repitieron una historia y un fracaso $^{44}$.

Hubo tres escenarios esos años. En la primera iniciativa después de abril de 1931, los católicos son aún la identidad de la nación. Por eso Ángel Herrera llama Acción Nacional al partido que crea. Por esas exigencias legales, deberá modificar su nombre por el de Acción Popular.

En el segundo escenario aparece la unidad política de los católicos, identificados con la derecha. Es la CEDA.

El tercer escenario supone aceptar gobernar la República con el sector liberal del Partido Radical. Cuando ese pacto termina, en febrero de 1936, la gente de la CEDA, a diferencia de Acción Española, ofreció, primero a Azaña, y luego a Casares Quiroga su apoyo para restaurar la legalidad en la calle y en el parlamento. Querían salvar la paz, pero no fue posible ${ }^{45}$. Ganaron la revolución y la contra-revolución. La sociedad española hizo de sus diferencias una inapelable llamada a las trincheras durante casi tres años.

Es significativo que abandonaran juntos la comisión parlamentaria para revisar las actas de las elecciones de febrero, su presidente, Indalecio Prieto, entonces en la zona templada del PSOE, y los miembros de la CEDA.

Entonces y ahora, la izquierda debe responder a un desafío que Albert Camus planteó con nitidez y argumentos éticamente irrebatibles: ¿acepta que no está ni por encima ni por delante del pueblo? ¿Está dispuesta a respetar los procesos electorales y sus resultados y el principio de legalidad? No lo supo hacer en 1933, cuando perdió. No lo supo hacer en 1936 cuando ganó. La revolución, reducida a un intento en octubre de 1934, es una evidente respuesta a esas preguntas ${ }^{46}$. La reacción provocada, sólo dieciséis meses más tarde, a partir de febrero de 1936, hizo de la evidencia una tragedia, que aún

42 Esta carta de Pío X a José María Salvador y Barerra, obispo de Madrid, 1906, a instancias del P. Luis Martín, prepósito general de la Compañía de Jesús, preocupado por las divisiones que había entre los jesuitas y que comenzaban a manifestarse públicamente.

${ }^{43}$ Eugenio Vegas, Memorias políticas. El suicidio de la Monarquía y la Segunda República, Barcelona, Planeta 1983, 131-132, 141, 165-166 y 305. La continuación, La frustración en la victoria: Memorias políticas, edición al cuidado de Emilio de Diego, Madrid, Actas 1995.

${ }^{44}$ Eugenio Vegas Latapié, Historia de un fracaso: El ralliement de los católicos franceses a la República. Catolicismo y república : un episodio de la historia de Francia, s.. y s.f., Madrid 1932, 175 pp.

45 José María Gil Robles, No fue posible la paz Barcelona, Ariel, 1968.

${ }^{46}$ El arzobispo de Tarragona así lo sostenía. Vidal i Barraquer-Pizzardo, 8 octubre, ASV AES Spagna IV pos. 856 fasc $2405-7$.

Hispania Sacra, LX

122, julio-diciembre 2008, 735-766, ISSN: 0018-215-X 
perdura, si se sostiene ahora que la transición de hace unos años habría sido un fiasco.

En el camino hacia la crisis de octubre de 1934, hay varios momentos. En seguida se afirma que la Iglesia y los católicos ante la República no buscan ni insurrección ni conjura, sino ejercicio de sus derechos cívicos. Un ejemplo fueron las manifestaciones públicas varias ciudades españolas en 1932, con motivo de la fiesta del Corazón de Jesús. Con ellas no se buscaba quebrar «la salud del régimen» ${ }^{47}$. Se limitaban los católicos a ejercer sus derechos, tal como los recogía la Constitución.

La sensibilidad de la izquierda ante esos actos revelaba que informaba su actividad el anti-catolicismo, su denominador común más poderoso y estable. Una buena política debía tener presente que los sentimientos religiosos y las creencias son factores que conmueven y movilizan a los pueblos. En el caso de los vascos, la República, poniendo como símbolo a Riego, elegía por héroe a un personaje que les recordaba las agresiones a su fe y la supresión de sus «imprescriptibles derechos ${ }^{48}$. «No va la Iglesia por su propio pie al campo de la política, se la arrastra con la arbitrariedad y la injusticia»49.

Frente a esa opción, los monárquicos, los extremistas de derecha, por temperamento o «por falta de visión», perseveraban en su teoría de «el mal mayor», que tan pésimos resultados dio en Francia. Acción Popular, agrarios, regionalistas y peneuvistas creían más urgente revisar la legislación que plantear el cambio de régimen, y ganar así la cooperación de los republicanos que no eran laicistas ni socialistas. Con 114 diputados Gil Robles podría gobernar, pero se le exigiría el reconocimiento expreso de la República.

El 9 de septiembre de 1933 se eligieron los vocales para el Tribunal de Garantías Constitucionales ${ }^{50}$. Fueron derrotados los candidatos ministeriales. Radicales y agrarios demostraron tener una gran fuerza, mayor de la esperada. En el País Vasco, ganaron los católicos, que casi sacaron cuatro veces más votos que las «candidaturas izquierdistas». El resultado, una descalificación de Aza-

\footnotetext{
${ }^{47}$ La reacción de la prensa de izquierdas ante el número de fieles que acudieron en Barcelona a la procesión del Corpus demostraba su olvido de lo que había sucedido en la ciudad cuando los radicales, mayoría en el ayuntamiento, suprimieron la subvención para ese acto. Aunque probaban que la justificación del Estado laico carecía de base social, nadie podría juzgar que fueran un acto de oposición al régimen. Joaquín $\mathrm{M}^{\mathrm{a}}$ NADAL, «Crónicas catalanas. La afirmación católica», La Gaceta del Norte 11 de junio de 1932,1 .

48 «La base anticatólica», La Gaceta del Norte 10 e junio, 1.

49 Réplica a las acusaciones de Luz contra el obispo de Barcelona, Manuel Irurita, «En defensa obligada. Ante una campaña insidiosa», La Gaceta del Norte 24 de noviembre, 1.

${ }^{50}$ Previsto en los artículos 121-124 de la Constitución, lo reguló la Ley Orgánica del 14 de julio de 1933., según determinada el artículo 124. Úna parte de sus miembros eran de elección por las Cortes, por las regiones, port los colegios de abogados y por cuatro profesores de las facultades de derecho.
} 
ña, que sostenía que el parlamento aún representaba la opinión. Mientras contara con mayoría en las Cortes, seguiría en su puesto ${ }^{51}$. No pudo ser y dimitió el gobierno. No era una solución, pero sí un alivio ${ }^{52}$.

Confiada a Lerroux la formación de gobierno en septiembre de 1933, volvía la derecha a plantearse el problema del régimen. Antonio Goicoechea y el conde de Rodezno deseaban restaurar la «monarquía tradicional». Creyendo que les desautorizaba el Papa, dijeron una frase «más propia de 'Action Française' que de católicos: 'El dogma en Roma, la política, en casa'».

Organizaron una campaña de telegramas manifestando adhesión al Papa y protestando por un artículo de L'Osservatore Romano que valoraban como un favor hecho a sus adversarios dentro de la derecha. El arzobispo de Tarragona recordó que, durante la monarquía, los católicos fueron orientados hacia la aceptación de los poderes constituidos. El poder del Estado, mayor hoy que nunca, exige «prepararse para el gobierno y asumirlo en el momento oportuno». Eso obliga al reconocimiento de las instituciones, porque «los monárquicos no podrán ejercer el poder sin un previo golpe de fuerza».

Sin ocupar el poder, era más difícil convencer a la opinión, situar en los organismos a personas dispuestas a defender el orden público y mejorar las leyes. La concentración monárquica desencadenaría la concentración de las izquierdas para salvar la República. Estas obtuvieron más de 5 de los 11 millones de votos. Interesaba mantener divididas a la izquierda y formar un partido conservador que pudiera turnarse con los radicales. Los monárquicos nada perderían con la formación de un fuerte partido de orden y conservador. No se sabía aún cómo evolucionaría la situación tras cambiar la mayoría parlamentaria ${ }^{53}$.

\footnotetext{
${ }^{51}$ Eran votos no «recusables», que revelaban que los españoles se habían alejado de «la actual tendencia socialista imperante». Los que trajeron la República desahuciaban a quienes la estaban usufructuando. «Otra gran derrota del Gobierno. Los candidatos antigubernamentales obtienen la mayor parte de las vocalías regionales en el Tribunal de Garantías. En las Vascongadas y Navarra, las candidaturas católicas obtienen 3272 votos contra 953 las izquierdas. «Las elecciones al Tribunal de Garantías», La Gaceta del Norte, 5 y 6 de septiembre de 1933, 1 y 3 y 3-4.

52 «El Gobierno Azaña se ha derrumbado. «Porque no siente quebrantada su autoridad para seguir funcionando», La Gaceta del Norte, 8 de septiembre, 1-2

53 «La verdadera victoria debe consistir en consolidar el triunfo alcanzado, actuando paciente, celosa y constantemente sobre las masas, instruyendo y formando la conciencia de los fieles por los medios que Dios ha puesto en nuestras manos, en especial por la $\mathrm{AC}$. Los integristas y legitimistas estaban usando la táctica de siempre: mutilar la posición de los obispos interpretando sus documentos de manera sesgada y en beneficio propio, como demostraban la campaña de El Siglo Futuro y un libro de J. Cirera PRAT, El criterio legitimista frente al confusionismo actual, Barcelona 1933. Vidal-Pacelli, Vidal-Pacelli, 6 de diciembre de 1933 y 15 de enero de 1934, Esglesia i Estat durant la Segona República Espanyola 1931/1936. IV 10 d'octubre de 1933/18 de juliol de 1936, Monestir de Montserrat 1986, 166-171 y 205-210.
}

Hispania Sacra, LX

122, julio-diciembre 2008, 735-766, ISSN: 0018-215-X 
Las elecciones supondrían el final de un período, afirmó Lerroux el 6 de septiembre en las Cortes. Esa había sido la práctica parlamentaria durante la Restauración. Hubo una crisis total y Lerroux dejó el gobierno el 9 de octubre de $1933^{54}$. En sus discursos posteriores al 12 de septiembre, Azaña definía su política con tres adjetivos: laica, social y autonómica. Su obra no fue una gestión de gobierno, sino la construcción de un Estado, que él llama «La República» ${ }^{55}$.

Del nuevo gobierno de Lerroux, los católicos, por vía directa nada podrían esperar directamente, pero sí indirectamente. Pese a los manejos que, a impulso del sectarismo, podría ejercer sobre los votantes, unas elecciones legislativas favorecían una nueva composición de las Cortes que frenara la agresión contra la Iglesia y permitiera una revisión constitucional, comenzando por las leyes aprobadas bajo la dirección de Azaña ${ }^{56}$.

$\mathrm{Su}$ aparente templanza podría perjudicar a los católicos, desmovilizarlos para que retornara a la indiferencia y a la pasividad. No había que engañarse. Lerroux había consentido la legislación patrocinada por Azaña ${ }^{57}$. Declaró que esas leyes, incluida la de reforma agraria, eran «intangibles» ${ }^{58}$.

El gobierno de Lerroux tenía un sólo objetivo: resistir firme frente al enemigo común, detener «la fuerza arrolladora de la derecha». Las elecciones recientes acababan de demostrar que los republicanos históricos podrían ser derrotados ${ }^{59}$. Había que preparar ese día. Se necesitaba voluntad. Nadie podría engañarse. Lo dijo tajantemente Lerroux. Las Cortes sobrevivirían a la caída de Azaña, porque proseguirían su programa: autonomía, laicismo, reforma agraria y reforma social ${ }^{60}$. Se

54 Una descripción de los acontecimientos, José PLA Historia de la Segunda República Española, II, Barcelona 1940, 354-365.

55 Santos Juliá, Manuel Azaña. Una biografía política, Madrid 1990, 308. Esa perspectiva varía en los discursos de campo abierto en 1935, tras la experiencia de la cárcel. Ahora se afirma que su política será «estrictamente basada en la Constitución, que nosotros declaramos hoy por hoy intangible», ib. 414.

56 Cuando se formó el gobierno presidido por Diego Martínez Barrios, volvió a recordar la necesidad de preparar las elecciones y de ir unidos y disciplinados a ellas. «Nuestro deber: aprendamos de las enseñanza del enemigo», La Gaceta del Nortee,10 de octubre, 1.

${ }^{57}$ El ejemplo eran los católicos de Alsacia Habían sabido separar lo discutible -la convocatoria hecha por un partido político- de lo incuestionable: la defensa de la religión. «Alsacia de nuevo se ha puesto en pie», La Gaceta del Norte, 25 de septiembre, 1.

${ }^{58}$ El periódico consideraba que el antiguo republicano no había cambiado desde 1909. «Lerroux, encargado del Poder y Signo de caducidad. Una pregunta», La Gaceta del Norte. 10 y 12 de septiembre, 1 y 3 . En la primera declaración ministerial, Lerroux prometería cumplir las leyes laicas y las agrarias. «El gobierno y su programa tienen un acentuado sentido izquierdista», La Gaceta del Norte, 30 de septiembre, 4 .

59 «Lerroux es, como lo fue Azaña, el aglutinante para los grupos sectarios: un aglutinante menos poderoso, esta es la verdad, que el que hasta ahora actuó de tal». «El camino a seguir», La Gaceta del Norte, 13 de septiembre, 1 .

${ }^{60}$ La posición respecto al jefe del partido radical, «Frente a Lerroux, como frente a cuantos ataquen la conciencia cristiana de nuestro pueblo», La Gaceta del Norte, 8 de noviembre, 8 . 
respetarían las leyes aprobadas en ellas ${ }^{61}$. Pese a esas declaraciones, el gobierno no obtuvo la confianza. Fue derrotado por 189 votos contra 91. Parecía que el único punto común entre los hasta entonces gobernantes era el laicismo beligerante. Si se iniciaba otras vías, las rencillas destrozaban la convivencia republicana ${ }^{62}$.

En un clima de confrontación, la derecha creyó que el otoño de 1933 iba a ser un momento decisivo. Las elecciones otorgarían la victoria a los socialistas o a un «frente antimarxista». Había que hacer una política «autoritaria». Gil Robles quería decir que el país necesitaba unidad y dirección para resolver sus problemas. En aquella hora de tensión y de equívocos, se pronunció por un Estado nuevo, beligerante contra «masones y judaizantes». Que concentrara el poder y usara la democracia como «un medio» para construir ese Estado nuevo. El parlamento sería destruido, si no se sometía ${ }^{63}$.

Entonces se publicó el libro del canónigo de Salamanca, Niceto de Castro Albarran sobre el derecho a la rebeldía ${ }^{64}$, un texto «imprudente e inoportuno» ${ }^{65}$. El libro fue detenidamente revisado por el obispo de Tortosa, Félix Bilbao ${ }^{66}$, que apostaba claramente por la línea de León XIII en Francia ${ }^{67}$. Comenzaba con esta obra el ataque «de la secta místico-político-bribonesca (como los llamaba Menéndez y Pelayo) para salirse con la suya: dividir a los fieles, al clero y al episcopado». Querían el fracaso del modus vivendi que se negociaba con la Santa Sede. El escrito de Albarrán estaba lleno de «insidia y falsedad», «instrumentos que emplean los que quieren pasar por acérrimos defensores de las doc-

${ }^{61}$ La inevitable crisis del sistema urgía a estar preparados. Lo estaba «el extremismo rojo». La derecha debía organizarse, porque la República padecía «una inestabilidad incorregible». «Lerroux se presenta a las Cortes» y «Hay algo que hace falta: querer», La Gaceta del Norte, 3 de octubre, 1. Puso las mismas objeciones a un posible gobierno Martínez Barrios. «Interrogante del momento» La Gaceta del Norte, 8 de octubre, 1.

62 «El gobierno Lerroux se derrumba en el fracaso» y «Por el prestigio del régimen», La Gaceta del Norte, 4 y 7 de octubre, 1-3. El voto transgredía la doctrina constitucional, porque, por elevación, apuntaba al jefe del Estado.

63 «Discurso de Gil Robles en el Monumental Cinema de Madrid», 15 de octubre de 1933, El Debate, 17 de octubre.

${ }^{64}$ El derecho a la Rebeldía, Madrid 1933. El examen de esta obra, ASV AES Spagna IV, posizione 842, fascicoli 221-222. Otras publicaciones recuperaban este aspecto de la moral católica en un ambiente de exaltación antirrepublicana.

65 Vidal-Pacelli, 23 de noviembre y 6 de diciembre de 1933, Esglesia i Estat durant la Segona República Espanyola 1931/1936 IV, ... 1986, 159-161.

66 Su dictamen, Esglesia i Estat... 251-263. Todo lo concerniente a esta obra, ib. 159-161 y 205.

${ }^{67}$ Era una rectificación al libro de Eugenio VEGAs LATAPIÉ, Catolicismo y república: un episodio de la historia de Francia, Madrid 1932. Recopilación de sus artículos en Acción Española, con el título «La Historia de un Fracaso». Un estudio, A. GAMBRA, «El «ralliement» en el pensamiento político de Eugenio Vegas. A propósito de su libro «Catolicismo y República», Verbo 239-240 (1985) 11161125 .

Hispania Sacra, LX

122, julio-diciembre 2008, 735-766, ISSN: 0018-215-X 
trinas cristianas y de la religión». Al cardenal Vidal i Barraquer le causaban «asco y hastío» 68 .

Encargado de formar Gobierno el 9 de octubre, Diego Martínez Barrio presidió las elecciones del 19 de noviembre. José Martínez de Velasco, en nombre de los agrarios, vetó las candidaturas de extrema derecha en el comité de enlace en el que estaban además tradicionalistas y Renovación Española69. En la segunda vuelta la minoría popular-agraria pactó con Lerroux. Gil Robles consideraba fundamental vencer a la izquierda, sin entrar en el dilema monarquía o república. No lo entendieron así los monárquicos. El problema del régimen continuó en primer plano ${ }^{70}$

En el País Vasco el censo electoral se modificó radicalmente. En todas las circunscripciones el voto femenino lo incrementó por encima del $100 \%{ }^{71}$. José María de Urquijo quiso que La Gaceta del Norte guardara silencio en todo lo que pudiera dividir a los católicos y avivar la polémica entre ellos en asuntos opinables. En septiembre de 1933, Mateo Múgica reiteró a sus diocesanos el mandato del Papa: que los católicos permanecieran unidos. Publicó unas normas, exhortando a la convivencia con todos, también con los que «en el campo social, político o incluso religioso sienten u obran de distinto modo» ${ }^{72}$.

68 Vidal-Ilundain, 8 de agosto de 1934, Esglesia i Estat... 440-2. Vuelve sobre lo mismo en su carta del 2-3 de septiembre de 1934, ib. 520-522, al informarle de la situación de la negociación. Esta misma denuncia Vidal-Pacelli, 18 de agosto, ib. 484-486. Recordaba que era cosa vieja en España, mencionando las tensiones durante el pontificado de León XIII y 1 vinculación de los legitimistas a la Action Française. Insistió en que debía llegarse a un arreglo, que fortaleciera a Niceto Alcalá Zamora y al propio Pita Romero, 26 de septiembre, ib. 531. La misma impresión tras la formación del gobierno Lerroux el 3 de octubre, Vidal-Pacelli, 3 de octubre, ib. 558.

${ }^{69}$ Sobre el ambiente en que se produjo esa decisión de dejar fuera a los más significados por su derechismo, Ramiro de MAEZTU, «A la rebatiña»: ABC 27 de octubre de 1933. La crítica a este comité, Santiago Galindo Herrero, Los partidos monárquicos bajo la Segunda República(2), Madrid 1956, 193-194 y 216-218.

70 J. M. Gil Robles, No fue posible la paz, Barcelona 1968, 92. Sobre su posición personal respecto a la monarquía, ib. 79. En 1937 creía que debía basarse en la voluntad nacional, garantizar los derechos de la persona, incorporar a todos los ciudadanos, realizar una transformación radical de las estructuras sociales y económicas. De no ser así, la forma debía subordinarse a los principios, la monarquía a los ideales políticos. El 21 de noviembre dijo a la prensa. «Nosotros hemos hablado de robustecer una política de centro para evitar los saltos bruscos continuos, que son perjudiciales». Habría que «actuar en el Poder». Citó un discurso de Maura en el Congreso el 3 de abril de 1883: «Las transacciones políticas a veces deshonran; pero la deshonra no proviene de haber transigido, sino de los móviles que han impulsado a transigir», ib. 105 y 115.

71 José Luis de la Granja, Nacionalismo y II República en el País Vasco, Madrid, Siglo XXI, Madrid 1986, 404. Hay una reedición en 2008.

72 Sobre las tensiones generadas entre el nacionalismo y otros sectores del catolicismo vasco, Francisco RodríGuez dEL CoRo, Catolicismo vasco, entre el furor y la furia. 1931-1936, Vitoria 1986, 188195 y $212-218$. 
Las elecciones del 19 de noviembre podrían iniciar la reconquista de todos los bienes espirituales, transitoriamente perdidos, detener la revolución y empezar la rectificación de «leyes persecutorias». En ellas la CEDA obtuvo una gran victoria. Eso supuso la entrada de personas nuevas en las Cortes. Para explicar esta incorporación de «jóvenes promesas», cabe señalar la postura accidentalista ante la República y el «reformismo social», la aportación del efímero PSP de 1922.

Hubo algo más. La CEDA «fue uno de los pocos partidos políticos españoles que supieron aunar hegemonía política con preparación técnica en su marcha general a partir de 1933». Fue una desgracia que la derrota de febrero de 1936 impidiera al partido ejecutar los planes que «sin duda deberían tener preparados» sus Comisiones de Estudio de Política Española» ${ }^{73}$.

Gil Robles, «esencialmente parlamentario», no quiso salirse de las reglas del juego. Jamás tuvo una veleidad dictatorial ${ }^{74}$. Rompió a CEDA la «lógica» del asalto al poder. Martínez de Velasco y Gil Robles resistieron la presión de los monárquicos. Acción Popular y el Partido Agrario, «pensando en España antes que en el régimen, tuvieron el patriotismo inteligente y generoso de prestarnos su concurso, ellos, los vencedores, a nosotros, los vencidos» 75 .

El 2 de diciembre Gil Robles se dirigió por radio a toda España. Concordia y justicia social eran su programa ${ }^{76}$. «Paz religiosa, paz social, paz política. Eso debe ser el año 1934»77.

\section{LA PECULIARIDAD VASCA}

El plebiscito vasco, del 9 de septiembre, en las elecciones para el Tribunal de Garantías Constitucionales, revestía asimismo una «importancia excepcional». Era la primera oportunidad que se ofrecía al pueblo vasco para pronunciarse sobre la autonomía. El proyecto no satisfacía a ninguno de los grupos po-

73 J. R. Montero, La CEDA. El catolicismo social y político en la II República, I, Madrid 1977, 551 y 744-745. Sobre el accidentalismo de la CEDA, ib. II, 40-88.

${ }^{74}$ Esta afirmación de José Plá es de 1941. Vid. o.c. III, Barcelona 1941, 66-69.

75 Presididas por un político de izquierdas, ganó una coalición defensiva de centro derecha, según la valoración de Francisco de Cossío. El error de la izquierda fue servir de coro a separatistas y socialistas. Quedaban así útiles para gobernar desde la legalidad únicamente los que entonces gobernaban con Lerroux. No había otra política. Fuera de ella, la demagogia y los enemigos de la república, Alejandro LeRrouX, La pequeña historia. Apuntes para una historia grande vividos y redactados por el autor. Buenos Aires 1945, 211-213 y 358-359.

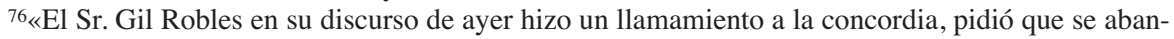
donen las ideas revanchistas y defendió un programa de justicia social, La Gaceta del Norte. 3 de diciembre, 4.

77 «El balance de 1933. Año difícil y angustioso», La Gaceta del Norte, 31 de diciembre, 1.

Hispania Sacra, LX

122, julio-diciembre 2008, 735-766, ISSN: 0018-215-X 
líticos con arraigo. No reconocía los derechos históricos. Era sólo un «avance» en las concesiones que sus «tutores oficiales» hacían a los vascos.

El futuro parlamento vasco una institución liberal y por tanto, antiforal. No era aceptable la forma de elección de sus miembros. Álava quedaría en minoría y perdería parte de su soberanía provincial, puesto que «a este parlamento se le confieren además toda las atribuciones del País». La única solución es una «representación IGUALITARIA» de cada provincia y que las facultades del parlamento se limiten a regular y ordenar las relaciones entre las provincias, los conflictos entre ellas y la representación conjunta ante el Estado, así como los servicios de interés general que le confieran las Juntas de cada Provincia. Si no, desaparecerían las diputaciones.

Someter la responsabilidad de jueces y magistrados a la intervención del pueblo conduciría a una justicia donde la Magistratura funciona en Convención, privando de su libertad al poder judicial ${ }^{78}$.

Elecciones legislativas y el plebiscito sobre el Estatuto movilizarán a los vascos. El voto femenino decidiría ${ }^{79}$. En esas circunstancias y respondiendo a sus lectores, iba a hablar La Gaceta del Norte, procurando, como siempre «servir tan sólo los intereses de Dios y del País Vasco». Su primera opción era la necesaria alianza electoral de los católicos en el País Vasco. Era un requisito para triunfar. Había que trabajar mirando no sólo al ámbito vasco, sino al de la nación, puesto que el estatuto debía conformarse con la constitución. El pacto electoral contaba con un medio que, a su vez, constituía un obstáculo. El primero: la claridad de las directrices de la jerarquía. El segundo, la costumbre de los católicos de actuar al margen de ellas ${ }^{80}$. Todo sabían que la unidad exigía generosidad y abnegación para ceder y transigir. Habría incluso que superar la repugnancia que pudiera causar el aceptar cosas contrarias a las propias posiciones partidistas. Eran indispensables la magnanimidad y el olvido de agravios, que alentaran rencor y desconfianza.

Sobre el plebiscito vasco, era un deber reclamar la plena reintegración foral. «No puede ser ideal para los católicos ningún proyecto autonómico que aparezca limitado por el marco de una Constitución sectaria y esencialmente laica, que impide el reconocimiento tácito y expreso de la personalidad espiritual del

\footnotetext{
${ }^{78}$ Carta del diputado a Cortes por Alava al diputado por Bilbao, José Luis de Oriol y Urigüen-José Horn Areilza, 29 de septiembre de 1933, Copia mecanografiada, AHN/GC P.S. Bilbao 103/21.

${ }^{79}$ Insistiría en este aspecto, comentando unas palabras de Prieto en la asamblea de la Agrupación Socialista de Bilbao. «Perfiles electorales. Del enemigo el consejo» $\mathrm{y}$ «El Liberal» y el voto de la mujer», La Gaceta del Norte, 27 de octubre y 1 de noviembre de 1933, 1.

${ }^{80}$ Se vivía en comunión con la Iglesia a través del Papa y de los obispos según San Ignacio de Antioquía, «Sobre la Jerarquía de la Iglesia. La educación ha de ser «positiva», La Gaceta del Norte, 2 de noviembre, 1 .
} 
Pueblo Vasco y de su fe religiosa inseparable de su historia y germen de vida de sus instituciones seculares».

El texto sometido a plebiscito otorgaba competencias, cuyo ejercicio favorecía al País Vasco, entre ellas, la de enseñanza y beneficencia. Se recogía el régimen de Concierto Económico. El movimiento autonomista había tenido en las tres provincias apoyo popular a través de sus ayuntamientos.

A todas estas razones en favor del voto afirmativo, se sumaba «el deseo de paz espiritual y de concordia entre los católicos vascos que perseguimos como bien supremo en todas nuestras actuaciones y que consideramos hoy hondamente amenazadas». Para soslayar las dramáticas consecuencias que derivarían de un voto negativo y preparar la alianza para las legislativas, todos los sacrificios eran pequeños ${ }^{81}$. Al pedir ese voto afirmativo, La Gaceta del Norte no tenían miras políticas ${ }^{82}$.

Cualquier duda de si esta era la decisión correcta quedaba despejada al conocer que Acción Republicana, los socialistas, los radical-socialistas y la UGT de Vizcaya anunciaron que votarían $n^{83}$. Había que desenmascarar el cinismo de quienes, como Azaña, venían al País Vasco a decir que no habían perseguido a los católicos y habían dejado en libertad a la Iglesia ${ }^{84}$.

El 5 de noviembre de 1933 el Estatuto recibió 4592554 votos positivos y 14196 negativos. Ese 90\% de adhesión se explicaba por la abstención de socialistas, republicanos y tradicionalistas ${ }^{85}$.

La derecha era sinónimo de catolicismo. Su triunfo en las elecciones legislativas del 19 de noviembre de 1933 fue una victoria para la Iglesia. «España volvía a ser católica». Esa interpretación dejaba en mal lugar a los nacionalistas que no habían querido formar parte de esa «unión salvadora». La respuesta de los nacionalistas fue afirmar que su victoria en el País Vasco tenía un significado claramente derechista desde el punto de vista religioso. Respondían de ese modo a quienes comenzaban a tacharlos de «irreligiosos, de masones, de ateos,

81 «Las elecciones y el Estatuto Vasco». «Fijando nuestra posición» y «La víspera del plebiscito» La Gaceta del Norte, 24-26 de octubre de 1933 y 4 de noviembre, 1. «El vasquismo de La Gaceta del Norte se relacionaba con la base carlista y nacionalista que nutría el bloque católico». Gabriel PLATA PARGA, La derecha vasca y la crisis de la democracia española (1931-1936), Bilbao 1991, 222, 233 y 272. Vid. también J. L. de la Granja o.c. 410-417 y 433-434.

82 «Ante el plebiscito. Se impone a serenidad», La Gaceta del Norte, 5 de noviembre, 1.

83 «Las izquierdas, sin pretenderlo, vienen a apoyar nuestra tesis. Porque al fijar su posición lo hacen situándose frente por frente a ella y señalándonos el terreno en que la batalla va a librarse». «En vísperas del plebiscito», La Gaceta del Norte, 3 de noviembre, 1.

${ }^{84}$ Resumen del discurso pronunciado por Azaña en San Sebastián el 3 de noviembre y comentario, «El Estatuto Vasco»y «Hay que barrer a Azaña». La Gaceta del Norte, 4 y 5 de noviembre, 8 y 1.

${ }^{85}$ Los resultados, sin comentarios, «El plebiscito del Estatuto Vasco», La Gaceta del Norte, 7 de noviembre 1 y 3 .

Hispania Sacra, LX

122, julio-diciembre 2008, 735-766, ISSN: 0018-215-X 
de fomentadores de un nuevo cisma en la Iglesia». El «Jelismo» era algo más que el nacionalismo ${ }^{86}$. Armonizaba la fidelidad a Dios y a la patria vasca. La doctrina de Sabino Arana no podría entenderse desde el laicismo o la aconfesionalidad. Estaba convencido de la religiosidad secular de los vascos. Juzgaba esencial esta dimensión en su identidad como pueblo ${ }^{87}$. «Ante el mundo la nación vasca tiene el distintivo de su recio espiritualismo cristiano» 88 . El nacionalismo mantuvo siempre este rasgo hasta cuando no fue entendido y aceptado por ciertas jerarquías de la Iglesia ${ }^{89}$, que sirvieron a quienes condenaban el que era «el más cristiano de los nacionalismos del mundo» ${ }^{90}$.

Los nacionalistas quisieron dejar definida su posición. En medio de la persecución, durante años, el PNV había llegado a ser la organización que orientaba la mayoría del pueblo católico vasco. Habían conseguido, en medio de un «océano rojo», poner en marcha un movimiento obrero fiel a las orientaciones de la Iglesia. Su actividad política, en las Cortes y en los ayuntamientos y diputaciones, demostraba con claridad que defendía los intereses católicos. Tenía derecho a que fuera públicamente reconocida su condición confesional y su fidelidad a ella. No reclamaban de los obispos cooperación, sino la «omisión que la prudencia aconseje en determinadas ocasiones». Los nacionalistas serían siempre hijos sumisos de la Iglesia en lo espiritual, pero «recabando la absoluta, la terminante libertad, el rotundo derecho que nos asiste para proclamar a Euzkadi nuestra patria y para defenderla contra toda negación, venga de donde viniere» ${ }^{91}$. Había mucho de turbio en quienes hablaban de religión para hacerla consustancial con sus apetencias políticas ${ }^{92}$.

86 «Las generaciones abertzales del futuro, ¿mirarán, pues, la libertad euzkadiana como fin absoluto de sus afanes? ¿O sólo verán en ella, a través de las doctrinas sabinianas, el medio humanamente indispensable para llegar a la recristianización del pueblo vasco?» Esta era la doctrina que había que sostener, huyendo de novedades, que, con el señuelo de unir a los patriotas, podría llevar a la catástrofe. Lucio de ARAKIL, «El porvenir del jelismo», Euzkadi, 21 de febrero y 1 de marzo de 1934, 1.

${ }^{87}$ LETARPI, «¿Irreligioso el jelismo?», Euzkadi, 4 de enero, 1. El artículo iba dirigido contra los tradicionalistas, que deseaban ligar a los nacionalistas con la monarquía. Sobre la insuficiencia de las promesas del primer pretendiente carlista Engracio de ARANTZADI, «Los carlistas en 1834» Euzkadi 7 de enero, 1.

88 «La impiedad es maketa», dijo Arturo Campión. El cristianismo penetró entre los vascos sin violencia. Engracio de ARANTZADI, «Catolicismo y nacionalidad vasca», Euzkadi, 3 de agosto de 1934, 1.

89 «... siendo solicitado para la defensa de los intereses religiosos, cuando se veían comprometidos por la chusma extraña y sectaria», padecía luego «persecuciones injustísimas y desmoralizadoras cuando llegaba la calma». Estas acometidas eran mucho mas dolorosas «por venir de donde venían y por a ingratitud inmensa que significaban y porque a nosotros, católicos empeñados en salvar la fe de nuestro pueblo, nos colocaban con esos ataques en trance de quedar solos». Engracio de ARANTZADI, «Ataques al nacionalismo. En nombre de la Iglesia», Euzkadi, 20 de junio de 1935, 1.

${ }^{90}$ Engracio de ARANTZADI, «Lope de Vega. Fiel reflejo de la sensibilidad religiosa española», Euzkadi, 30 de agosto, 1 .

91 «Derechos y deberes», Euzkadi, 11 de enero de 1934, 1.

92 «El P.N.V. en 1933. Vivo, entre las ruinas», Euzkadi, 15 de marzo de 1934, 1. 
Siempre católicos, los nacionalistas jamás mezclaron la religión con la política ${ }^{93}$. Durante años, los alfonsinos se atribuyeron esa nota, sin recatarse de denominarse, al mismo tiempo, liberales. Los tradicionalistas usurparon ese nombre e invadieron con la política zonas vedadas a quienes deseaban obedecer a la Santa Sede. Los nacionalistas acataron siempre los poderes constituidos por razones de bien público. Habían asegurado de ese modo la paz en los dos primeros años de la República. Frente a la agresión de los gobiernos de la izquierda, presididos por Azaña, los nacionalistas resistieron toda incitación a la violencia. Vivían, según ordena la Iglesia, dentro de la legalidad, «preparándose en ella para tiempos mejores» ${ }^{94}$. Esta posición solitaria de los nacionalistas, dentro de la Iglesia, se correspondía en política con el centro ${ }^{95}$. De las izquierdas les separaba el «abismo de la fe». Las derechas los agraviaban negando los lazos de religión y raza que les unían y tratándolos como a sus peores enemigos, aunque los llamaban en los días de peligro. Permanentemente los agredían y agraviaban no con palabras, sino con su «acción reiterada» ${ }^{96}$.

\section{DESDE LEÓN XIII A LA DILECTISSIMA NOBIS}

Tras las elecciones de noviembre de 1933, era preciso retornar a deberes permanentes. Como decía Jaime Balmes, debajo de la superficie política hay siempre una realidad social. La política era un medio para intervenir en ella. «No lo fiemos todo al triunfo de la política y menos a la organización modelo de oficinas electorales». Hay que crear el elector, es decir, al ciudadano capacitado para entender las situaciones sociales, económicas y políticas y pronunciarse ante ellas. Era una parte de la educación moral en una sociedad democrática ${ }^{97}$. Era al

\footnotetext{
${ }^{93}$ Además de por convicción, los nacionalistas era cristianos «por vascos». Ikasle-Ingokija. Página semanal a cargo de Bizkai'ko Ikasle - Batza, «Cristiano y Vasco», Euzkadi, 10 de mayo, 1.

94 «Por encima de los intereses de los partidos y de los pueblos están los de la religión. Mezclarlos es, sobre todo, indigno, peligrosísimo». Engracio de ARANTZADI, «Lo temporal; lo eterno», Euzkadi, 29 de abril, 1. Sabino Arana subordinó siempre lo patriótico a lo católico. «Larrazabal y El aniversario del juramento de Larrazabal», Euzkadi, 3 de junio, 1 y 3 . El acto conmemoraba la promesa de fidelidad al lema JEL que pronunció Sabino Arana el 3 de junio de 1893.

${ }^{95}$ Así quedaba reflejado en las caricaturas publicadas en Euzkadi el 8 y el 12 de mayo.

96 «El que en estas circunstancias sea atacado el nacionalismo por católicos y por vascos, en nombre a veces, muchas veces, de la Iglesia y de los intereses del pueblo vasco» hería a los militantes del PNV. Dolía mucho más que la «hostilidad exótica» de las izquierdas. Engracio de ARANTZADI, «Derechas e izquierdas, Euzkadi, 9 de mayo, 1.

97 «Las gentes, que reciben con un sonrisa desdeñosa el anuncio de un círculo de estudios, de una cátedra de doctrina social, de una mejora periodística, de una nueva revista de orientación filosófica, económica o jurídica, y solamente piensan en el recuento de fuerzas y en las próximas elecciones, no han llegado a la altura del gravísimo momento que vivimos». «Tiempos de renovación y Un oportuno recuerdo», La Gaceta del Norte, 25 y 26 de noviembre, 1.
}

Hispania Sacra, LX

122, julio-diciembre 2008, 735-766, ISSN: 0018-215-X 
mismo tiempo una opción para que la Iglesia jamás abandonara la libertad alcanzada al independizarse del poder y al reconocer la libertad política de los católicos ${ }^{98}$.

La preparación, desde la responsabilidad, que iniciaban los católicos en diciembre de 1933, buscaba recuperar sectores alejados que, decepcionados en algunos casos, habían llegado a odiar el catolicismo ${ }^{99}$. En las conferencias morales y litúrgicas para los arciprestazgos de la diócesis de Vitoria, se propuso el estudio del pensamiento de León XIII, Sapientiae Christianae y Humanum genus. Habría que desmontar los sofismas contra la religión. Los católicos debían confesar su fe públicamente. En el curso 34-35, se estudió la Dilectissima nobis, de Pío XI ${ }^{100}$, en torno a este temario: uso de medios legítimos, educación religiosa, acción católica y unión de los fieles, deber de los padres católicos en relación con la instrucción de sus hijos y apoyo a las escuelas católicas. Identificada la República con la secularización, la tarea principal era «la recristianización completa de la sociedad» ${ }^{101}$.

Cuando eran tan amplias y apremiantes las labores pendientes, el catolicismo «político» proseguía bloqueando con conflictos internos el horizonte de la Iglesia. El Siglo Futuro criticó a los prelados. Lo había amonestado ya varias

${ }^{98} \mathrm{La}$ «era nueva» inaugurada con la Acción Católica significaba esa independencia, que generaba una influencia «menos aparatosa, pero más profunda, por medio de la educación de las conciencias». «La Acción Católica y la política e Ideas fundamentales. La Acción Católica y la política», La Gaceta del Norte, 28 de enero y 15 de abril de 1934, 1.

${ }^{9}$ En la Semana Social de Madrid (15-22/10/33), Maximiliano Arboleya dijo: «No es simplemente indiferencia, es odio reconcentrado, odio de una ferocidad inhumana, el que sienten (los obreros) hacia la Iglesia... Nos han abandonado, pero continúan odiándonos». Cit. por V. M. ArbeloA, Aquella España Católica, Salamanca 1975, 134.

100 La encíclica de Pío XI en cuanto se conoció la orientación política del Gobierno provisional. En octubre había ya un texto. Lo corrigió el Papa. Estaba listo el «Schema definitivo di un'enciclica sulla Spagna, pronto nel Novembre 1931; ma poi rimasto sospeso». En 1932 se le añadieron correcciones. Debería ser un texto amplio. Podría tacharse de que llegaba tarde. Su condición de encíclica podría empeorar la situación de la Iglesia en España. Iba a discutirse la Ley de Confesiones y Asociaciones Religiosas. Era la prueba de que la República continuaba la tradición regalista. Pese al reconocimiento de la libertad de conciencia, la ley consagraba la supremacía del Estado, controlando todas las actividades, las personas y los bienes de lo que en el texto se designaba como Congregaciones y asociaciones religiosas, denominación usada para la organización de la Iglesia católica. Los esquemas, los textos y sus vicisitudes pueden seguirse en ASV AES Spagna IV pos.833 fasc. 208-209.

${ }^{101}$ Esa misión se presenta enmarcada en símbolos bélicos: hay una guerra generalizada contra Jesucristo y su Iglesia en todos los sectores de la vida social. Es una obligación de los católicos salir en defensa de los intereses supremos que estaban en juego. Vid. la pastoral de Múgica sobre las Jornadas de Acción Católica, que tuvieron lugar en las tres capitales de la diócesis. Alberto Onaindía, en las conferencias que pronunció en esta ocasión, subrayó la posición marginal de la Iglesia respecto a instituciones tan importantes como la escuela, la universidad, la prensa y el cine. Sobre el papel de la AC en la recuperación de la sociedad para la Iglesia, vid. la «Memoria sobre la situación de la Juventud Católica en Vizcaya», con fecha 23 de diciembre de 1933, Joaquín PEREA, El modelo de Iglesia subyacente en la pastoral del clero vasco (1918-1936), Bilbao 1991, 283, 491-493 y 468-470. 
veces, sin resultado el obispo de Madrid, Leopoldo Eijo Garay. La posición del cardenal Vidal i Barraquer era benevolente. Convenía la existencia de diarios católicos de diversas tendencias, con tal que no se combatieran ${ }^{102}$.

Así las cosas, César González Ruano evocó la figura del cardenal Segura, arzobispo de Toledo, que renunció a su sede en septiembre de 1931. El primado, «al margen de toda política, no supo ni quiso pactar. Esa (fue) la enseñanza máxima y el máximo símbolo del cardenal Segura»103. Los intransigentes acusaron a Gil Robles y a la CEDA, porque toda transacción era siempre una inmoralidad ${ }^{104}$.

José Bergamín denunció el laicismo de los republicanos. La separación Iglesia-Estado y la neutralidad de la escuela habían funcionado como medios de persecución contra los católicos ${ }^{105}$. Prieto declaró ante las nuevas Cortes que no creía en la sinceridad de los católicos. Jamás serían leales a la República. Juan Ventosa dijo que esa afirmación convertía el régimen en una ideología.

La izquierda no aceptaba el resultado de las elecciones de noviembre. En el mitin de la Plaza de Toros de Barcelona. El domingo 7 de enero de 1934, intervinieron Azaña, Prieto y Marcelino Domingo. Azaña censuró la disolución de las Cortes, aun reconociendo que estaban ya separadas de la opinión. Confesó

102 Vidal Barraquer-Pacelli, 3 de noviembre de 1933, Església i Estat...1986, 140-141. El nuncio recordaba la pretensión mayor que había caracterizado al diario integrista: tener el monopolio del catolicismo». Esa era la peor censura que podría hacerse a los integristas. Confidencial y reservada. Tedeschini-Vidal, Ávila 18 de noviembre de 1933, ib. 153-156.

103 «Estampa del buen Cardenal», ABC, 9 enero 1934. Desgraciadamente esta imagen se ha impuesto. Más allá de sus actitudes personales, presentes en su proyección como arzobispo, sobre todo en sus relaciones con los otros obispos y la Santa Sede, no puede decirse que el cardenal Segura no conociera y expusiera la diferencia entre principios políticos y gestión política, que ignorara el deber de acatar el poder constituido, que no fuera parco en su agradecimiento a Alfonso XIII y que tardara en recordar que los católicos debían obedecer a las autoridades republicanas. Lo hizo El Castellano en su edición del 16 de abril. Parece que su biógrafo hubiera deseado que el mismo 15 de abril, el cardenal Segura hubiera ido a saludar o ponerse a las órdenes de un «Gobierno provisional», venido tras unas elecciones que no eran legislativas. Sobre los antecedentes de esta postura del cardenal Segura, su pastoral de febrero de 1930 y us declaraciones en abril de 1931, Andrés MARTínEz EsTEBAN, «El magisterio episcopal en el reinado de Alfonso XIII», Los obispos españoles ante los conflictos políticos del siglo XX, José María Magaz (editor), Madrid, Publicaciones de la Facultad de Teología «San Dámaso» 2008, 66-68. El reproche al cardenal por no apresurarse a presentarse ante las nuevas autoridades, Francisco Gil Delgado, Pedro Segura. Un cardenal de fronteras, Madrid, Editorial Católica, BAC $616,2001,210-232,239-244,257,273$ y 283.

104 En el ambiente que hemos indicado en el capítulo anterior, hay que encuadrar el texto de Manuel SENANTE, Verdadera doctrina sobre el acatamiento, obediencia y adhesión a los poderes constituidos y sobre la licitud de la resistencia a los poderes ilegítimos y de hecho. La política tradicionalista, editado por El Siglo Futuro, Madrid 1932.

105 Así la Ley de Congregaciones, que ampliaba de tal manera los preceptos constitucionales, que los tergiversa lesionando derechos reconocidos y amparados por la misma Constitución. Alejandro LERROUX, La pequeña historia... Buenos Aires 1945, 201-202.

Hispania Sacra, LX

122, julio-diciembre 2008, 735-766, ISSN: 0018-215-X 
que la ley electoral se hizo al gusto y en beneficio de la izquierda. Y ponderó la libertad de prensa, ocultando que, durante su mandato, había suspendido 114 periódicos.

Marcelino Domingo se manifestó más jacobino: «Cuando una política que beneficia al pueblo se encuentra con que el pueblo no la quiere, tiene que imponerse incluso contra la voluntad del pueblo. España con la República se entregó a las izquierdas y quedó incorporada a una nueva civilización. Las derechas tienen obligación de transigir sin protesta y consolidar la obra revolucionaria» 106 .

Semanas más tarde, en abril de 1934, se fundó Izquierda Republicana. Sus dirigentes eran Azaña, Casares Quiroga, Luis Bello y Marcelino Domingo ${ }^{107}$. «Sin dejar de ser liberales ni demócratas - dijo Marcelino Domingo- hemos de evitar que España vuelva a caer en manos impuras. Mientras la República no esté consolidada, no haya cumplido plenamente su obra, hay que actuar de forma que no vuelva a ofrecer la misma realidad angustiosa que ofrece ahora y aprendiendo de las dictaduras que, cuando se está en el período revolucionario, el primer deber es fortalecer y crear el Estado»108.

La ambigüedad había cambiado de residencia. Ahora se domiciliaba en la izquierda, que estaba con un pie en el Parlamento y otro en la barricada. Anunciaban la revolución social mientras practicaba la obstrucción en las Cortes ${ }^{109}$. La libertad cambiaba de bando. Se alojaba en quienes hasta ese momento eran sospechosos de no creer en ella. Se alejaba de quienes la identificaron con democracia, en los días de «la fiesta de la República».

106 «»Ya lo saben las derechas», La Gaceta del Norte, 10 de enero de 1934, 1.

107 Azaña era un «estadista de opereta», según José María Cid, ministro de Comunicaciones. Haciendo suya esta calificación, se le acusaba de haber «gobernado con saña». Su paso por el poder le cerraba cualquier posibilidad de regreso. «Actos políticos en Alicante» y «Funesto e incorregible», $L a$ Gaceta del Norte, 22 de mayo, 1. El periódico subrayó las conclusiones del debate parlamentario sobre Casas Viejas. «La vista de la causa por los crímenes de Casas Viejas», La Gaceta del Norte, 25 y 26 de mayo, 1-2 y 7 y 1-2. La causa fue remitida al Tribunal Supremo. «Los crímenes de Casas Viejas», $L a$ Gaceta del Norte, 27 de mayo, 1-3. Sobre la tragedia de Casas Viejas, puede verse el relato de Ramón J. Sender, Casas Viejas, estudio preliminar de Ignacio Martínez de Pisón; edición de José Domingo Dueñas y Antonio Pérez LasHeras; notas de Julita Cifuentes, Zaragoza, Prensas Universitarias de Zaragoza Huesca : Instituto de Estudios Altoaragoneses, 2004.

108 «Esencias democráticas. El nuevo partido de izquierdas», La Gaceta del Norte, 8 de abril, 1. La crónica de acto que tuvo lugar en el cine Pardiñas, organizado por las Juventudes de Izquierda Republicana y un resumen de los discursos de Azaña, Casares y Domingo, el 16 de abril, «Predican la revolución, porque todo está podrido desde que ellos no mandan», La Gaceta del Norte, 17 de abril, 1.

109 «No lo pueden tolerar esto ni el Gobierno ni las fuerzas de la derecha». Si el partido socialista se pasaba a la revolución, entonces se colocaba fuera de la ley. «Discurso de Gil Robles en Sevilla», 4 de enero de 1934, CEDA 19 (15 de febrero de 1934) 4. 


\section{DOS TESTIGOS, DOS HORIZONTES}

A esta nueva forma de presencia, abierta con la Inmortale Dei en noviembre de 1885, muchos consagraron hasta 1936 tiempo, inteligencia y dinero. Dos de ellos son testigos de lo que supuso en aquellos días, aún oscuros, procurar la paz, trabajar por ella sin descanso y rehuir la violencia. Escaparon de la resignación y de la cólera. Los dos pertenecían a ese grupo de gente que aporta lo suyo porque creen, esperan y responden a los que es bueno, a lo que es un reto humano o un deber ético, diciendo «Por mí no ha de quedar», Se trata de José María de Urquijo ${ }^{110}$ y Ángel Herrera ${ }^{111}$.

El primero creó La Gaceta del Norte. Frente a la derecha política, defendía el reforzamiento de unos principios sociales. Se oponía al poder absoluto del Estado. Comentaría con escándalo que Ramiro Maeztu justificara el asalto al poder de Hitler en Alemania ${ }^{112}$.

La identificación religión y política tenía para él un sentido inverso al que le daban los totalitarios de la derecha. La línea editorial de La Gaceta del Norte no identificaba patria y catolicismo. Sus páginas hablaban de los deberes políticos de los católicos y de los medios para cumplirlos. A diferencia de su colega El Pueblo Vasco no empleó la retórica de la violencia. No patrocinó, en su confrontación con la República, las llamadas «virtudes militares», la belicosidad, la marcialidad, el sentimiento heroico, el irracionalismo patriótico, en su versión de un españolismo esencial e indiscutible ${ }^{113}$.

El modelo era el Zentrum alemán y los católicos franceses tras la ley de separación ${ }^{114}$. La opción de los católicos alemanes durante el régimen de Bis-

${ }^{110}$ C. Robles, José María de Urquijo e Ybarra. Opinión, religión y poder, Madrid, Consejo Superior de Investigaciones Científicas 1997.

111 José María García Escudero, De periodista a Cardenal: vida de Ángel Herrera, Madrid, Editorial Católica, Biblioteca de Autores Cristianos, 1998. Ángel HerRERA ORIA, Obras selectas, edición preparada por J. M. Sánchez de Muniain y J. L. Gutiérrez García, Madrid, La Editorial Católica, 1963. El pensamiento de Ángel Herrera: antología política y social, por José María Garcia Escudero, Prólogo por Alfonso Ibáñez de Aldecoa, Madrid, La Editorial Católica, 1987.

112 Condenó rotundamente el régimen nazi. Si la orientación política de Hitler lograra imponerse y extenderse a otros países, sería una desgracia para la humanidad. Revelaría «una de las grandes taras del alma moderna». «Las doctrinas totalitarias y el cristianismo integral», La Gaceta del Norte, 1 de julio de 1933,1 .

113 Gabriel Plata Parga, La derecha vasca... 118-120 y 127-128. No hay que confundir la vehemencia con la que José María de Urquijo pediría, durante el primer bienio, una resistencia civil, que Plata Parga considera que eran llamadas a la violencia y que da veracidad a su tesis de que estuvo en los preparativos de un alzamiento militar contra el régimen. Al mismo tiempo, reconoce que esas expresiones son más «arrebatos» que desafíos concretos, ib. 190.

${ }^{114} \mathrm{El}$ primero fue un partido inter-confesional, sostenido por la corriente sindical inter-confesional. Hizo el «Ralliement» a finales del siglo XIX. Se defendió del integrismo antimodernista en tiempos de Pío XI. El segundo se identificó como «popular y liberal», recuperando para este término el sentido

Hispania Sacra, LX

122, julio-diciembre 2008, 735-766, ISSN: 0018-215-X 
marck se confirmó en Francia. Los católicos demostraron luego en las trincheras su patriotismo y las dificultades permitieron la aparición de «un cristianismo consciente y fecundo», Los tenían como la única salida compatible con la doctrina católica sobre el origen del poder.

Confiaba José María Urquijo en la capacidad de los católicos para realizar su presencia eficaz en la sociedad y para modificar la legislación desde la legalidad, sin recurrir a la insurrección contra los poderes constituidos.

El mismo día en que se produjo la insurrección de Sanjurjo, el 10 de agosto de 1932, La Gaceta del Norte evocaba la experiencia alemana, «una lección que no deben desaprovechar los pueblos católicos oprimidos por poderes sectarios. La clave de su triunfo está en haber sabido dar un contenido social a su organización, es decir, en haber forjado una red de periódicos, asociaciones... «. La Acción Católica era una vía de penetración social, de carácter civil y pacífico, un medio para recuperar el predominio social y político de la Iglesia ${ }^{115}$.

Creyó José María Urquijo que a los católicos, estando unidos, les bastaba el recurso de las leyes y una generosidad sin tasa para que no faltaran medios al proyecto de León XIII: ir al pueblo y servirlo. Lo asesinaron el 5 de setiembre de 1936. Se ha escrito que José María de Urquijo tuvo ese final por ser «un batallador entusiasta de los ideales de la Religión» ${ }^{116}$.

Murió asesinado por pertenecer a esa minoría, siempre condenada al fracaso, que apuesta por la justicia y la conciliación. «Extraño a todos los partidos y exento de odios y rencores, no pronunciaré una sola palabra que pueda excitar la discordia y provocar a venganza; y sea cual fuere el resultado de los vaivenes que agitan a esta nación desventurada, siempre podré decirme con entera satisfacción de una conciencia tranquila: no has pisado el linde prescrito por la ley, no has exasperado los ánimos, no has atizado el incendio, no has contribuido a que se vertiera una gota de sangre ni a que se derramara una sola lágrima» ${ }^{117}$. En su tumba una inscripción de tres palabras: «Testis Christi occisus».

de «protección al débil» frente al poder, que tuvo el liberalismo en sus mejores tiempos. Vid. «En el corazón de la democracia. Del «ralliement» a la separación», Anthologica Annиа 40 (1993) 247-455. La «vigilancia de Pío X y el del «Sodallitum Pianum» sobre el Zentrum y los sindicatos interconfesionales, ha dejado una abundante documentación en el ASV Fondo Benigni. Es un asunto que debe incluirse en el llamado «modernismo social».

115 Es verdad que había otros enfoques, como el de Esteban Bilbao, un tradicionalista, presidente de la Junta de Acción Católica en Bilbao, que juzgaba que la principal tarea era enfrentarse con la revolución roja y todas las organizaciones que funcionaban a su servicio. Sobre Esteban Bilbao y los otros miembros de la Junta, Gabriel Plata, o.c. 197-199.

116 «Las víctimas de la barbarie marxista en Guipúzcoa», El Pueblo Vasco, 5 de septiembre de 1937, 6-8.

${ }^{117}$ Esta cita de Balmes, repetida muchas veces, resumía toda la inspiración de La Gaceta del Norte desde su aparición en 1901. «El día de la Prensa Católica. Palabras de serenidad y anhelos de concordia», La Gaceta del Norte, 24 de junio de 1934, 1. 
El segundo testigo fue Ángel Herrera En un informe, redactado el 17 de septiembre de 1931, tras la aplastante victoria electoral de los partidos representados en el Gobierno, decía: «Si la política en España se desarrolla normalmente, las cosas pueden mejorar mucho para la Iglesia, en los meses venideros» ${ }^{118}$.

Este era su calendario: a fines de 1931, Constitución y crisis del gobierno. Lo presidirá Alejandro Lerroux, que disolverá las Cortes. Nuevas elecciones y una mayoría de 250 diputados para Lerroux. Los socialistas se hundirán: bajarán a unos 50 ó 60. Perderían casi la mitad. Los radical-socialistas quedarían casi extinguidos. La derecha podría llegar a unos 100 diputados $^{119}$. No fue en entonces, porque se mantuvieron las Cortes Constituyentes, . pero sí en las primeras elecciones a Cortes ordinarias, las del 19 de noviembre de 1933, como hemos visto.

La izquierda, decía Herrera, combatirá sin cuartel a ese gobierno de Lerroux. Buscará entonces el apoyo de la derecha en el parlamento y en la prensa. La derecha debe prestárselo «sincera y generosamente», reclamando que se resuelva enseguida la cuestión religiosa, de modo que los católicos recobren una paz que ahora no tienen.

Será el momento del concordato, porque entonces la Santa Sede tendrá en España un sólido punto de apoyo para defender sus derechos.

En un Gobierno Alejandro Lerroux, estaría como ministro de Hacienda Santiago Alba, persona que sería bien recibida en los círculos económicos y financieros de España. Salvador de Madariaga, culto y con buenos contactos en Ginebra, París y Londres, podría ser el ministro de Estado. Sin ser católico, era un moderado, con sentido histórico, admirador de la España de los siglos de oro. Esto significaba que conocía y estimaba la deuda de España con la Iglesia.

Si Marcelino Domingo, radical socialistas, fuera ministro de Instrucción, sería una desgracia, porque «es un sectario, de criterio cerrado, que odia lo católico». Su modelo es la escuela laica, única y obligatoria. Incluso durante la monarquía, ese ministerio causó la «descristianización de España». Hay que intensificar el trabajo para convencer a los católicos de que su tarea debe concentrarse en la escuela, que iba cayendo en manos de la masonería.

En julio y agosto de 1931, socialistas e intelectuales republicanos se habían movido en contra de Alejandro Lerroux. Su candidato para presidir el Gobierno era Manuel Azaña. Dudaba Ángel Herrera de la moralidad de Azaña, conocía su animadversión a la Iglesia y apuntaba la reforma del ejército. Le reconocía talento y lo juzgaba bastante culto. Su elección sería un gravísimo peligro para los católicos.

118 Informe manuscrito de Ángel Herrera, 17 septiembre 1931, ASV AES Spagna IV 788 137 13-19.

119 Ángel Herrera presentaba una distribución provincial del previsible voto de la derecha. 
Saldos estos dos riesgos, el de Marcelino Domingo y el de Azaña, este horizonte no puede desagradar a los buenos republicanos. «La República no se consolidará en España sin el concurso de los católicos, y los republicanos comprensivos lo saben. No debemos regatear el concurso soñando con la aventura de una restauración. Si la restauración llega, vendrá por los errores y por las torpezas de los republicanos, no por las campañas civiles o militares de los monárquicos. Si volviera la monarquía por otra parte, los católicos actualmente en política, cooperarían con la Monarquía, fieles al principio de acatar los poderos constituidos de hecho». La monarquía, en ese caso, no los excluiría, porque los necesitaba.

La victoria, como pasa siempre, será de quienes trabajen sin descanso, se acomoden a las circunstancias de cada día, «por procedimiento ciudadanos». Los que sigan ese método están siempre «en la mejor posición, pase lo que pase, para servir a la Iglesia y a España».

Habría que recomendar a los católicos «este camino de la sumisión y colaboración con el gobierno, como ya lo han hecho los prelados de España». Era de justicia decir que la opinión católica seguía en general esas instrucciones. Era una novedad respecto al pasado.

Acción Nacional era la organización política que agrupaba a elementos de la derecha. Ángel Herrera pedía el apoyo privado de los obispos. Dejaba a un lado las formas de gobierno. Acataba el poder establecido y defendía la religión, la patria, la familia, el trabajo y la propiedad. Había que asegurar su el futuro como organización política.

«Mi criterio es que, si logramos salvar, con algunas concesiones, este delicado momento constituyente, podremos el día de mañana ganar el terreno perdido. Si se va a la ruptura, sabe Dios cuándo se reparará el daños»120.

Pasado un tiempo, unas semanas antes de que estallara la guerra civil, se envió a Roma un informe sobre Ángel Herrera. Era el 31 de mayo de 1936.

Los defectos personales de Ángel Herrera están mezclados con sus excepcionales cualidades y sus virtudes. Algunos le censuran que sea terco, frío, algo absorbente. Pero la acusación fundamental es que desarrolla una labor política y se vale para ello de la Acción Católica. Como un deber de conciencia, tratando de ser imparcial y con la debida reserva, y como consiliario general de la Acción Católica, el obispo de Tortosa, Félix Bilbao, apuntaba como punto débil de Ángel Herrera que era «algo de descuidado» en cuanto a las finanzas.

${ }^{120}$ Gil Robles-Tedeschini, 9 septiembre 1931, anexo a 5218Tedeschini-Pacelli, 13 septiembre ASV AES Spagna IV 788137 31-32. 
«Espíritu superior y hombre de gran fe, ve desde lejos los fines a conseguir y discurre sobre los medios de conseguirlos, descuidando acaso, a veces, esta parte económica, con cierta confianza de que, a la larga, los medios vendrán. Pero comprometiendo entre tanto intereses que también merecen respeto. Su vigorosa personalidad confía en el triunfo, pero hace pasar apuros a los que tiene como colaboradores» ${ }^{121}$.

Ángel Herrera llevaba veinte años estudiando la doctrina pontificia y formando según ella a jóvenes que ocupaban ya puestos de importancia. Con ese mismo objetivo había dirigido El Debate. Había logrado que fuera uno de los diarios más serios y mejor informados, «más caritativamente escritos y técnicamente perfectos».

Sus principios eran: formar minorías selectas; hay que actuar; hay que sumar; obediencia al poder constituido; renuncia a la violencia y no disputar entre católicos.

Esta era la historia. Tras el 14 de abril se apoderó de los católicos la tristeza y el abatimiento. Con todo se logró un grupo de diputados que defendieron los derechos de la Iglesia en las Cortes Constituyentes. Los partidos carlistas e integristas se reorganizaron. Se unieron como «tradicionalistas». A ello se incorporaron algunos alfonsinos. Las bases de ese acuerdo las redactó Antonio Goicoechea.

$\mathrm{El}$ «bloque» católico se fraccionó en dos grupos. El de los monárquicos con Renovación Española a su cabeza, y el de los agrarios y populares, que no se presentaban como enemigos de la República. Había un grupo fascista minoritario, Falange Española.

El sectarismo, las persecuciones y «el desquiciamiento económico» de los gobierno de Azaña, provocaron una respuesta. El resultado fue el triunfo parcial de la derecha en noviembre de 1933. Se llegó luego a un gobierno de centro-derecha, con los radicales, que arregló la economía y se mantuvo el orden público, pero no se cambiaron las leyes.

La reacción de la derecha de intereses, los ricos, fue retirar la ayuda a la CEDA y «perder el miedo, rebajando salarios oprimiendo a los débiles». La Izquierda se unió. La extrema derecha hostigó también al Gobierno. La derecha ministerial tuvo poca visión, «algún tanto de entonamiento u orgullo y poco afán de atraer».

A las elecciones de febrero acudieron las izquierdas unidas, explotando un asunto sentimental como la amnistía, con muchos medios, pero sin ostentación, con una buena dirección y ocultando su fuerza.

${ }^{121}$ Hasta sus amigos, la puntualización es mía, decían que Ángel Herrera era a veces un soñador, diseñando grandes proyectos, cuya viabilidad no estaba estudiada. Pero Maximino Romero de Lema y Emilio Benavent, añadían: muchas cosas se han hecho gracias a que Ángel Herrera se atrevió a pensar en ellas y a soñar con la idea de realizarlas.

Hispania Sacra, LX

122, julio-diciembre 2008, 735-766, ISSN: 0018-215-X 
Alcalá Zamora cometió el error de negar la jefatura del Gobierno a Gil Robles y dársela a Portela Valladares, que ni siquiera tenía un diputado.

Las derechas fueron a las elecciones divididas entre los monárquicos y los «colaboracionistas» con la República. Su propaganda espectacular asustó. Su dirección fue vacilante. Portela Valladares abandonó el Gobierno la misma noche de las elecciones, antes del recuento oficial. Se adjudicó la victoria la izquierda obteniendo una bonificación de mayoría de 50 diputados

Vinieron entonces el desorden y los atropellos ${ }^{122}$. La dirección del «partido popular» quedó desacreditada. Los «buenos» estaban muy tentados a la violencia. Eso daba pie a la represión por parte del Gobierno. La gente se desanimó. Dejó de colaborar en el mantenimiento del orden y en la solución de los problemas.

En ese momento se confunde a la CEDA con la Acción Católica y se acusa a Ángel Herrera de ser el alma del partido. Eso no podía aceptarse. Su intervención era una manera práctica de realizar las encíclicas. A cambio de todo lo positivo hecho, se le combatía con «saña, con notable falta de caridad y a veces acaso injustamente. Esa enemiga perjudica a la Acción Católica, pero hay que señalar que proviene de «círculos aristocráticos» de Madrid. En el resto de España se limitaba a una campaña de prensa, que infringía claramente las normas de la Santa Sede ${ }^{123}$.

Ángel Herrera esos mismos días se preparaba para marchar a Friburgo (Suiza) e iniciar sus estudios eclesiásticos en aquella Universidad Católica. Ordenado sacerdote, regresó España. Lo que hizo desde entonces fue continuar su trabajo. Eso mismo. Dicen que en la habitación donde murió había dos teléfonos. Dicen que se extrañó de que aceptaran su renuncia como cardenal obispo de Málaga. Dicen... Debajo de su aparente terquedad, de su carácter absorbente, quedaba manifiesto que era, sobre todo, un trabajador. Siempre lo fue. Hasta el final.

En historia los recuerdos valen como. Con dos puntos arriba expuestos se cierran estas líneas. El primero: el de aquel portugués que en 1933 se preguntaba si los católicos sabían en qué mundo vivían. Para orientarlos les dijo: las monarquías desaparecerán en Europa y la separación Iglesia-Estado en Portugal era intocable. El segundo, es un reto pendiente en la izquierda y en la memoria cultivada por ella: su tendencia a sustituir a la sociedad, a colonizarla, a camuflar todas las conductas de dominio y control. El error de sentirse guía, van-

122 Un inventario de los desórdenes a partir de febrero de 1936, José PLA, Historia de la Segunda República española, Barcelona, Destino, 1940, tomo IV. Ha sido reeditada por Destino en el 2006, en un solo volumen. Curiosamente, la Web de la Fundación Pla y la biografía trata de silenciar u ocultar esta obra. Lo escrito por Pla puede verificarse documentalmente con lugares y fechas.

123 «Acción Católica Española», informe de Félix Bilbao, 31 mayo 1936, ASV AES Spagna 794 $16511-14$. 
guardia... le ha llevado a abusos denunciados permanentemente por Albert Camus a lo largo de su obra ${ }^{124}$. Esa izquierda es revolucionaria. Hace el juego a una extrema derecha tan jacobina como ella. Lo denunció Unamuno en 1898125. Fue una de las causas de la guerra en 1936 y del fracaso de los gobiernos republicanos y de los presididos por Largo Caballero y Juan Negrín ${ }^{126}$.

En este recuerdo-conclusión, hay que consignar si los cristianos aceptan seriamente la separación Iglesia-Estado. Sin gracias a ella gana en libertad dentro de sus Iglesias. Y si, de ese modo, cada Iglesia puede pueda elegirse desde sí misma, sin claudicar ante otras instancias.

124 «La verdad es misteriosa, huidiza, y siempre está por conquistar. La libertad es peligrosa, tan apasionante como difícil de vivir». Hay que crear y creer «entre las policías de tanta ideología (¡cuántas iglesias, cuanta soledad!)». Aunque desfallezcamos, porque el camino es largo, «debemos marchar hacia esos dos objetivos». Albert CAmus, «Discurso en Suecia», palabras en la ceremonia de entrega de los Premios Nobel y Conferencia en la Universidad de Upsala, 10 y 14 de diciembre de 1957, en Obras, 5, Madrid 1996 pp. 168 y 174. He reflexionado sobre esta perspectiva en «León XIII y la memoria de un catolicismo que nació libre», Hispania Sacra 113 (2004) 289-332.

${ }^{125} \mathrm{El}$ integrismo convirtió en España la fe religiosa en algo «muy picudo, agresivo, cortante y de aquí ha salido ese jacobinismo seudo religioso, que llaman integrismo». Carta a Ganivet, publicada por Ganivet en el verano de 1898 en El Defensor de Granada recogida El porvenir de España y editada en Idearium español / El porvenir de España, edición de Inman Fox, Madrid, Espasa Calpe 1999, 191.

${ }^{126}$ Manuel AzAÑa, Causas de la guerra de España, prólogo de Gabriel Jakson, Barcelona, Grupo Editorial Crítica, 1986.

Hispania Sacra, LX

122, julio-diciembre 2008, 735-766, ISSN: 0018-215-X 